\title{
ANOTHER PASS-THROUGH BITES THE DUST? OIL PRICES AND INFLATION
}

\author{
Autores: Óscar Landerretche, \\ José De Gregorio y \\ Christopher Neilson
}

Santiago, May. 2007

La serie de Documentos de Trabajo (SDT) del Departamento de Economía de la Universidad de Chile en versión PDF puede descargarse en la dirección electrónica www.econ.uchile.cl/SDT . Para contactar al editor ejecutivo de SDT remitirse a sdt@econ.uchile.cl 


\title{
Serie Documentos de Trabajo \\ N 238
}

\section{ANOTHER PASS-THROUGH BITES THE DUST? OIL PRICES AND INFLATION}

\author{
Óscar Landerretche \\ Departamento de Economía \\ Universidad de Chile \\ José De Gregorio \\ Banco Central de Chile \\ Christopher Neilson \\ Banco Central de Chile
}

\begin{abstract}
This paper presents evidence of an important decline during recent decades in the pass-through from the price of oil to the general price level. We find that this decline is a generalized fact for a large set of countries. After documenting correlations between the consumer price index and oil prices, we use two estimation strategies in an attempt to properly identify the effect of oil shocks on inflation. First, we estimate the traditional Phillips curve augmented to include oil and test for structural breaks in 34 countries. This methodology shows a fall in the average estimated pass-through for industrial economies and, to a lesser degree, for emerging economies. Second, we estimate rolling vector autoregressions for a subsample of countries for which we have sufficient data. We derive impulse response functions of inflation to oil shocks and interpret the integrals as estimates of pass-through. We find that the effect of oil shocks on inflation has weakened for most of the 12 countries in the sample. Among the factors that might help to explain this decline, we argue that the most important are a reduction in the oil intensity of economies around the world, a reduction in the exchange rate pass-through, a more favorable inflation environment, and the fact that the current oil price shock is largely the result of strong world demand. These factors help to explain not only why the current shock has had limited inflationary effects, but also why it has had limited consequences for output.
\end{abstract}




\section{Resumen}

Se encuentra que tal disminución es generalizada para un amplio conjunto de países. Luego de documentar correlaciones entre el índice de precios al consumidor y el precio del petróleo, se utilizan dos estrategias de estimación en un intento por identificar adecuadamente el efecto inflacionario de los shocks del petróleo. Primero, se estima la curva de Phillips tradicional para 34 países, aumentada de modo de incluir el petróleo y testear si existe quiebre estructural. Esta metodología muestra una caída en el traspaso medio estimado para los países industrializados $y$, en menor medida, para las economías emergentes. Segundo, se estiman vectores autorregresivos en ventanas moviles para una submuestra de países para los que existen datos suficientes. Se derivan funciones de impulso respuesta de la inflación a los shocks petroleros, y se interpretan las integrales como estimaciones del traspaso. Se encuentra que el efecto de los shocks petroleros sobre la inflación se ha reducido en la mayoría de los doce países de la muestra. Entre los factores que podrían explicar esta caída, en nuestra opinión los más importantes son que la intensidad económica del petróleo se ha reducido en el mundo, que también ha disminuido el traspaso del tipo de cambio, que el ambiente inflacionario es más favorable, y que el actual shock del precio del petróleo es el resultado de una sólida demanda mundial. Estos factores ayudan a entender no solo por qué el actual shock ha tenido efectos inflacionarios limitados, sino asimismo por qué sus consecuencias en el producto también han sido limitadas.

\section{Palabras Claves:}

Oil, Inflation. 


\title{
Another Pass-through Bites the Dust? Oil Prices and Inflation ${ }^{\dagger}$
}

\author{
José De Gregorio \\ Banco Central de Chile
}

\author{
Oscar Landerretche \\ Universidad de Chile
}

Christopher Neilson

Banco Central de Chile

This Draft: April 2007

\begin{abstract}
This paper presents evidence of an important decline during recent decades in the pass-through from the price of oil to the general price level. We find that this decline is a generalized fact for a large set of countries. After documenting correlations between the consumer price index and oil prices, we use two estimation strategies in an attempt to properly identify the effect of oil shocks on inflation. First, we estimate the traditional Phillips curve augmented to include oil and test for structural breaks in 34 countries. This methodology shows a fall in the average estimated pass-through for industrial economies and, to a lesser degree, for emerging economies. Second, we estimate rolling vector autoregressions for a subsample of countries for which we have sufficient data. We derive impulse response functions of inflation to oil shocks and interpret the integrals as estimates of pass-through. We find that the effect of oil shocks on inflation has weakened for most of the 12 countries in the sample. Among the factors that might help to explain this decline, we argue that the most important are a reduction in the oil intensity of economies around the world, a reduction in the exchange rate pass-through, a more favorable inflation environment, and the fact that the current oil price shock is largely the result of strong world demand. These factors help to explain not only why the current shock has had limited inflationary effects, but also why it has had limited consequences for output.
\end{abstract}

JEL Classification: E30, E31, F41, Q43

Keywords: pass-through, oil price, oil usage, inflation.

\footnotetext{
${ }^{\dagger}$ We wish to thank Christian Broda, Rómulo Chumacero, Kevin Cowan, Juan Pablo Medina, Rodrigo Krell, Roberto Rigobon, Klaus Schmidt-Hebbel, Claudio Soto and participantes at the Economia-LACEA panel, and seminars at Banco Central de Chile and Universidad de Chile for helpful comments and suggestions. Contact: jdegrego@bcentral.cl, landerretche@econ.uchile.cl, cneilson@bcentral.cl.
} 


\section{Introduction}

A salient feature of recent oil price hikes has been the reduced impact that they seem to have had on general price levels worldwide when compared with previous oil shocks. This paper gathers stylized facts on the evolution of the pass-through of oil price changes to general inflation for a broad number of countries, in order to quantify this decline and to evaluate various hypotheses that might explain it.

The current surge in oil prices has also been associated with small effects on output. We find suggestive evidence that can explain both this association and the reduced impact on inflation. We show that a decline in the exchange rate pass-through, a reduction in the use of oil per unit of GDP, and a macroeconomic environment characterized by low inflation (which, among other things, has limited the reaction of monetary policy to these events) help to explain the relatively mild effects of the current oil shock on the global economy. Although we focus on the inflationary consequences, the factors we highlight are also consistent with the limited effects of the current oil shock on global economic activity.

The casual observation that inflation is lower now in many countries than in the 1970s and 1980s, despite increased oil prices, is not a definitive demonstration of a lower pass-through. In the first place, although nominal oil prices have recently set new records, real oil prices are not as high as they were in those earlier decades. Also, the high inflation of the 1970s and 1980s was not due to the oil shocks alone; macroeconomic policies then were very accommodative of inflationary shocks. The improved macroeconomic policies in many countries today may have contributed to a smaller pass-through. Finally, oil prices are not entirely exogenous to the general equilibrium of the world economy, and the reaction of world inflation and output to an oil price rise will depend on its nature, namely, whether it results from a fall in supply or from strong demand.

An oil shock is the classic supply shock in traditional macroeconomic models. Labor becomes more expensive in all sectors of the economy as workers adjust their inflation expectations in the wake of the shock. Margins fall throughout the economy, and aggregate supply contracts, pushing prices upward. Agents rapidly calculate through the equilibrium of the economy and end up compounding these price hikes into a larger pass-through. On the other hand, if wages are inflexible, (perhaps because firms are locked into long-term collective labor contracts), most of the macroeconomic adjustment to an oil shock should take the form of higher unemployment rather than higher inflation, with stagflation as the macroeconomic result. Since the 1980s, labor markets worldwide have, if anything, become more flexible; hence, within this framework, one should expect larger pass-throughs and shallower recessions from oil shocks. However, the impact of the recent oil price increase on both inflation and economic activity has been small.

A somewhat more modern view would include the reaction function of the economic authorities. Here the choice of exchange rate regime, monetary target and 
cyclicality of fiscal policy become critical. Strict countercyclical fiscal policies would increase the pass-through and reduce output costs by boosting aggregate demand when production is more expensive. Strict inflation targeting would, on the other hand, reduce the oil pass-through, either through the direct compensatory effects of interest rates or through increased credibility of monetary policies. In the first case, the output costs of the shock are increased, whereas in the second they are not. Increased exchange rate flexibility among oil importers should increase the volatility of oil price inflation in terms of domestic currency. Thus increased countercyclicality of fiscal policies combined with the worldwide trend toward inflation targeting and greater exchange rate flexibility leads to an ambiguous effect on both the pass-through and the output costs of oil shocks. However, stable fiscal policy together with credible inflation targets could help to explain the recent evidence.

Current macroeconomic models stress how inflation shocks are related to the complete structure of costs in an economy. Inflation should react differently to oil shocks that differ in their expected persistence. Hence one could argue that the passthrough for recent oil shocks has been lower because these shocks were expected to be only temporary spikes (like those of 1990 and 1999) rather than the long-lasting hikes that they turned out to be. However, as we show in section 6 , recent futures contracts reflect the growing belief of market participants that current high oil prices will persist, yet inflation has not increased substantially.

It can also be argued that globalization and increased competition (China, WalMart, etc.) have limited producers' ability to pass their higher costs on to consumers. Producers engaged in stiff competition might rather take a transitory cut in their profit margins than give their competitors an opportunity to increase their market share. However, it is unclear why persistently higher costs for all producers worldwide would not be passed on eventually. This argument would predict a fall in corporate profits in industrial countries as a result of the oil shock, leading eventually to faltering investment and growth. Instead, and adding to the paradox, the current oil shock is correlated with higher corporate profits and healthy global growth.

Obviously, the theoretical case for reduced pass-through is not clear cut. There are valid arguments that would lead one to expect increases in the pass-through, but also valid arguments for reductions; in the end, which set of effects predominates is an empirical question. We will use alternative econometric methods to identify the pass-through and to observe its evolution over time in a variety of countries. We will show that one important factor that substantially helps to explain the observed facts is the average reduction in the oil intensity of economic activity in countries around the world.

This paper is related to the literature on the decline of the exchange rate passthrough, not only in a methodological sense, but also because it is possible that the explanations for both phenomena are related. Evidence for reduced exchange rate pass-through for industrial economies can be found in Campa and Goldberg (2002), and for a broad sample of countries in Borensztein and De Gregorio (1999) 
and Goldfajn and Werlang (2000), among others. Most of this work measures the decline in the pass-through but does not identify its causes. Taylor (2000), Choudhri and Hakura (2006), and Gagnon and Ihrig (2001), however, find that a low-inflation environment was an important cause of the reduced exchange rate pass-through in the 1990s. In analyzing the inflationary effects of currency depreciations, it is possible to argue that purchasing power parity does not hold at the micro level, but recently Burstein et al. (2005) have found that the explanation for a small exchange rate pass-through is that the response of nontradable goods is slow. Therefore, in the context of oil, we can interpret a lower pass-through as limited "second round" effects of oil on inflation, which certainly depend on the degree to which inflationary expectations are anchored. Recent work on exchange rate pass-through by Frankel et al. (2005) uses narrowly defined commodities and finds, among other things, confirmation that the inflation environment is important in explaining pass-through. Thus the exchange rate pass-through literature reveals that microeconomic as well as macroeconomic factors affect the way changes in exchange rates are transmitted to the general price level.

The effect of oil shocks on inflation has received less attention, although several authors have studied the impact on U.S. inflation and output. Mork (1989), and more recently Hamilton and Herrera (2001) and Davis and Hamilton (2003), argue that nonlinearities and asymmetries are the main features behind the observed relationship between oil and prices. Hooker (2002), on the other hand, estimates Phillips curves and tests for breakpoints to study changes in the oil price pass-through for the United States. He finds that the pass-through falls after the 1980s and that neither nonlinearities nor the reduced dependency of the economy on oil and on energy generally can explain the bulk of this fall. Hooker's evidence also supports the idea that a low-inflation environment is important in keeping the pass-through down. Finally, Barsky and Kilian (2004) emphasize that oil shocks are endogenous to the U.S. economy and argue that such shocks are not as important as is generally thought in explaining the stagflation of the 1970s in the United States.

The main contribution of this paper is to extend the calculation of the passthrough of oil price rises to inflation to a larger set of countries, and to verify whether the recent fall in the pass-through is limited to the United States or is generalized to the world economy. We find that the pass-through has fallen worldwide during the last 30 years. The cross-country nature of our investigation allows us to study in greater detail the factors underlying the decline in the pass-through and mitigates the problem of endogeneity of the oil price that US centered studies might face.

In section 2 we report the main stylized facts on which we base the econometric investigation. In section 3, following the methodology of Hooker (2002), we estimate the pass-through by augmenting a Phillips curve model with oil parameters. We then proceed to estimate multiple breakpoints for the model for each country. In section 4 we adjust the estimations to control for the exchange rate pass-through and the decline in oil intensity, both of which help to explain the decline in the inflationary 
impact of oil price changes. In section 5 we estimate rolling vector autoregressive models and calculate the impulse responses of oil shocks on the economy for a smaller (because of data limitations) sample of countries. In section 6 we review the available hypotheses on the decline of the oil pass-through as well as the main stylized facts that support each of them. The concluding section is followed by appendices with extended tables.

\section{Stylized Facts}

The conventional wisdom is that large oil shocks have historically been followed by high inflation in many countries, and even by hyperinflation in some. The top two panels of Figure 1 plot the nominal price of oil against the average inflation rate for industrial (left panel) and emerging economies (right panel; note the different scales in the two panels) since 1970. ${ }^{1}$ The bottom-left panel tracks the 24 -month nominal percentage change in the price of oil since 1970; the five oil shocks typically identified in this literature (1973, 1979, 1991, 1999, and 2004) are clearly evident. The bottom-right panel compares these oil shocks in more detail, showing that the four most recent shocks were similar in intensity when measured this way, whereas the first shock seems to have been much stronger. The 1991 shock seems quite transitory compared with the others, and the current shock seems to be one of the longest lasting.

The trajectories of average inflation rates seem quite different in the two sets of economies. In the industrial economies, a secular reduction in inflation rates starting in the mid-1970s was followed by an interruption in the early 1980s, after which inflation continued to fall, finally stabilizing at about 2 percent a year. Emerging economies had inflation rates comparable to those in the industrial countries in the early and mid-1970s.

Inflation then steadily increased through the 1980s, peaking in the late 1980s and early 1990s. Around the mid-1990s average inflation rates for the emerging economies began to fall and by now seem to have converged, hovering around 5 percent since the turn of the century.

Despite these differences, both series share a strong positive reaction to the oil shocks of the 1970s (the 1973 shock caused by the Yom Kippur War and the 1979 shock sparked by the Iranian Revolution). There is also a common positive reaction to the 1991 oil shock (the Persian Gulf War), although the effect seems to have been longer lasting among emerging economies; inflation in the industrial countries suffered only a temporary deviation from its downward trajectory. Also note that in some periods oil prices and industrial-economy inflation move very closely in tandem. These episodes might be thought of as high-pass-through periods, although there was no exceptional situation in the oil markets during these periods (e.g., the second

\footnotetext{
${ }^{1}$ All three series are from the International Financial Statistics database of August 2006. The quarterly inflation series is the year-on-year percentage change in the consumer price index.
} 
half of the 1980s and the years immediately following the Asian crisis). Obviously, looking at simple correlations is not enough.

Figure 1: Oil and Inflation over 40 Years
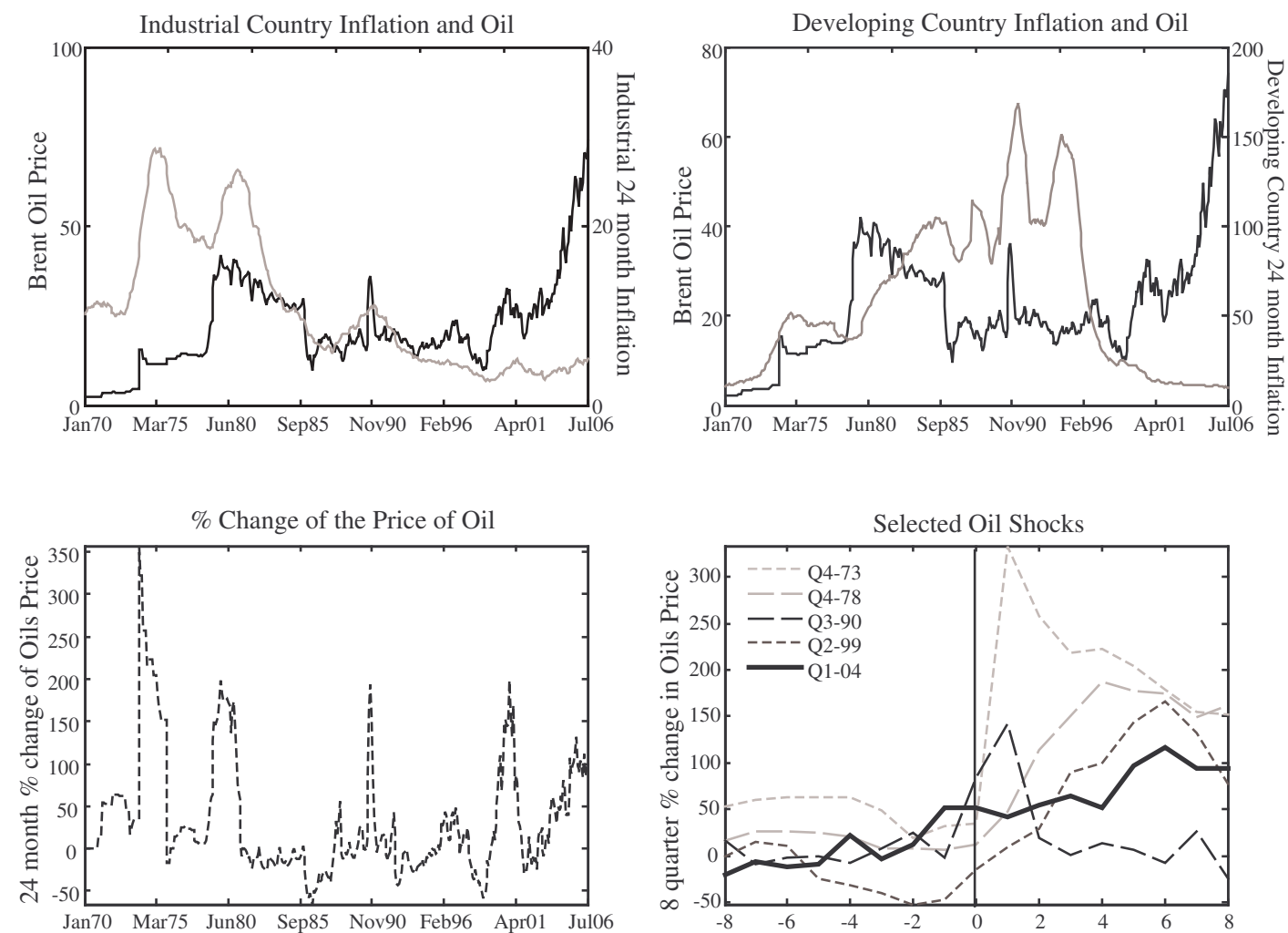

Note: The $\mathrm{x}$-axis of the bottom right panel shows time in quarters before and after the oil shock which is fixed at 0 .

Source: International Financial Statistics, September 2006

A simple way of describing the relationship between oil shocks and inflation is to calculate the simple pass-through coefficient of oil price inflation to general inflation. This coefficient is usually defined as the ratio between general price-level inflation and oil price inflation for a given horizon. It is typically presented in the exchange rate pass-through literature as a measure of how much of a given devaluation has been passed on to the domestic inflation rate. Table 1 shows passthrough coefficients for four oil shocks. We define an oil shock as an event where oil prices rise more than 50 percent in a year and the price rise persists for at least 6 consecutive months. ${ }^{2}$.

\footnotetext{
${ }^{2}$ The pass-through coefficient makes sense only when the change in price persists until at least the end of the horizon for which its being calculated. Otherwise the variation that has been undone is not taken into account. This is why the 1990-91 Persian Gulf war shock is not included in our
} 
Table 1: Pass-Through Coefficients, Inflation, and Oil Shocks (all \% changes are over 8 quarters)

\begin{tabular}{||c|cccc||}
\hline & \multicolumn{4}{|c||}{ Start of shock period } \\
Indicator & $1973 \mathrm{Q} 4$ & $1979 \mathrm{Q} 1$ & $1999 \mathrm{Q} 2$ & $2004 \mathrm{Q} 1$ \\
\hline Pass-through coefficient & & & & \\
Industrial economies & 0.20 & 0.25 & 0.11 & 0.06 \\
Emerging economies & 0.23 & 0.33 & 0.14 & 0.12 \\
Inflation (percent a year) & & & & \\
Industrial economies & 31 & 28 & 8 & 6 \\
Emerging economies & 35 & 37 & 11 & 10 \\
Change in inflation (\% points) & & & & \\
Industrial economies & 11 & 8 & 2 & -1 \\
Emerging economies & 10 & 14 & -6 & -6 \\
Change in oil price (percent) & & & & \\
Nominal & 154 & 148 & 132 & 116 \\
Real & 99 & 92 & 107 & 88 \\
\hline
\end{tabular}

Note: Coefficients represent the ratio between accumulated inflation and oil price change for a 24 month horizon. $\Delta$ in inflation represents the level change from the 24 month period after the oil shock vs the previous 24 month period. Individual episodes of high inflation $(\pi>\mu+3 \sigma \approx 100 \%)$ were eliminated to avoid distortions.

This criterion captures, as expected, the oil shocks of 1973-74 and 1978-79, as well as those of 1999-2000 and 2004-05. The price spike associated with the 199091 Persian Gulf war is not identified as a shock, however, because of its brevity. Interestingly, the 1999 and 2004 oil shocks were precipitated, like the others, by events in the Middle East, but other developments, mainly strong demand, helped keep prices high. The 1999 shock was caused by a political regrouping of the OPEC countries, which had lost cartel discipline over the years as non-Arab members entered. Although this event triggered the price hike, it is generally accepted that prices were sustained by strong demand due to rapid economic growth in the United States and China. In 2003, several supply-side factors, such as the Iraq war and later the escalation of the Nigerian civil war and the hurricane disasters in the Gulf of Mexico, again caused oil prices to rise sharply. However, one of the main causes behind the current oil shock is unrelenting world economic growth, particularly in China. Some have pointed to an additional possible source of demand driving prices upward, namely, the speculative positions taken in the oil market by agents seeking higher yields. In all, it does seem that the most recent oil shock has many more sources than did previous ones.

The first two rows of Table 1 show average oil pass-through coefficients in in-

definition in Table 1. 
dustrial and developing economies for a 24-month window following each oil shock. These coefficients were very similar in the mid-1970s but then diverged as both increased in the late 1970s. By the late 1990s, both pass-through coefficients had fallen, and by the time of the Iraq war they had fallen further, especially among the industrial economies. To avoid outliers we have excluded all individual episodes of inflation over 100 percent, most of which occurred in the 1970s, so that we do not overweight hyperinflationary episodes in our sample of emerging economies.

Table 1 also shows, in the third and fourth rows, average inflation levels during each episode in the two groups of economies. High inflation seems to be correlated with high pass-through coefficients, just as in the exchange rate pass-through literature. The next two rows show the change in average inflation in the two years before and after the oil price rise. It seems that a central difference among the four oil shocks is that the first two shocks correlate with significant increases in inflation, whereas the two most recent shocks are correlated either with stationary (in the case of industrial economies) or falling (in the case of emerging economies) inflation. Finally, the last two rows in Table 1 show the relative size of the oil price rise over the 24-month horizon. The last two oil shocks are comparable in magnitude to previous ones, both in real and nominal terms, although they occurred in an environment of lower inflation.

Obviously, the data in Table 1 face all the problems and limitations to which unidentified correlations are subject. In particular, when oil prices and inflation move together, it may be that we are not properly identifying the effect of one on the other, but rather observing the consequences of shocks on other markets or parameters. In the next two sections we use econometric methods to more precisely identify the impact of oil shocks on inflation by controlling for other relevant variables in the economy.

\section{Oil Passthrough and Structural Breaks in the Tradi- tional Phillips Curve}

In this section we follow Hooker (2002) in estimating the effect of oil prices on reduced-form Phillips curves. ${ }^{3}$ We estimate a traditional Phillips curve equation with several lags of inflation, the output gap, and the percentage change in oil prices. We extend this estimation to the broadest set of countries possible, estimating oiladjusted Phillips curves for 34 economies, of which 24 are industrial and 12 are emerging.

Preferred Phillips curves for different countries vary substantially in specification. For example, they frequently include dummy variables that reflect common knowledge among economists of structural breaks or other anomalies in the econ-

\footnotetext{
${ }^{3}$ See Rudd and Whelan (2005) and Galí et al. (2005) for a review and discussion of alternative forward-looking Phillips curves and their empirical relevance.
} 
omy in question. For example, for the United States, dummies for the Nixon price controls usually improve these estimations substantially; in emerging economies, dummies for particularly violent social and economic events usually prove useful. These dummies are usually quite noncontroversial but are also quite critical, especially in emerging markets (more so in those with periods of hyperinflation).

Although the structure of the Phillips curve thus varies from country to country, we choose to sacrifice the fitness of our estimations on the altar of comparability and do not include dummies for any country. In addition, to expand the sample of countries as far as possible, we use either industrial production or real GDP indices as proxies for economic activity, depending on their availability. ${ }^{4}$ The details of the data used are presented in Appendix 1.

The evidence presented in the previous section suggests there has been a decline in the correlation between oil price shocks and inflation. We therefore test the regressions for multiple structural breaks on all parameters following Bai and Perron $(1998,2003)$.

\subsection{Estimating the Pass-Through}

We estimate a generalized Phillips curve of the following form:

$$
\pi_{t}=\alpha+\sum_{i=1}^{4} \beta_{i} \pi_{t-i}+\sum_{i=0}^{4} \gamma_{i}\left(y_{t-i}-\bar{y}_{t-i}\right)+\sum_{i=0}^{4} \theta_{i} \mathrm{oil}_{t-i}^{u s \$},
$$

where $\pi$ is the quarterly percentage variation of general CPI index, $y$ is the log of quarterly percentage change in the industrial production or GDP index, $\bar{y}$ is the Hodrick-Prescott filtered trend of $y$ and $o i l^{u s \$}$ is the quarterly percentage change in the price of a barrel of Brent crude oil in U.S. dollars.

The full passthrough from an oil price shock to inflation, $(\phi)$ is obtained by inverting equation (1), which is

$$
\phi=\frac{\sum_{i=0}^{4} \theta_{i}}{1-\sum_{i=1}^{4} \beta_{i}}
$$

To study how the pass-through coefficient may have changed, we divide the time series and estimate the parameters for each segment. It is, however, preferable to determine potential breaks in the relationship given in equation (1) endogenously and we procede to do this by testing the specification of the Phillips curve for

\footnotetext{
${ }^{4}$ We are aware that this choice of variables could lead to substantial defects in the quality of our measure of output gaps. For example, some emerging economies in the last few decades have to some extent deindustrialized as a result of trade liberalization, and instead have specialized in other activities in which they have comparative advantage (e.g., India in services). Although these processes usually happen over a longer horizon than economic fluctuations, it is nevertheless also true that they could make industrial production indices quite nonrepresentative of the economy as a whole. In any case, and considering the scarcity of quarterly aggregate production data, we still view industrial production data as a reasonable proxy for economic activity.
} 
multiple structural breaks as suggested in Bai and Perron (1998). This methodology assumes that the dates $\left(T_{i}\right)$ and the number of structural breaks $(m)$ can be jointly estimated with the parameters using the least squares principle. For example, in the case of one break $\left\{\beta_{i}, \gamma_{i}, \theta_{i}\right\} \equiv \delta$ are estimated for each possible break date $T$. In this way, $\left\{\beta_{i}, \gamma_{i}, \theta_{i}\right\}$, are a function of the break date, and this break is chosen so that it minimizes the sum of the squares of residuals among all $T$.

Having found the structural breaks in the estimation of equation (1), we use these breaks to estimate the pass-throughs for the countries in our sample. Hence, rather than imposing breakpoints, we allow the data to show us when the pass-throughs have fallen, and we allow the breakpoints to differ across countries. ${ }^{5}$

\subsection{Results with Estimated Breakpoints}

Before estimating the oil-adjusted Phillips curves for each of the countries in our sample, we estimate it for all industrial economies in the aggregate. Interestingly, we find a structural break in 1980, just after the Iranian oil shock. The estimated passthrough falls from around 0.15 to 0.03 . The economic interpretation is as follows: before 1980, a 100 percent increase in the price of Brent was passed through as an increase of 15 percentage points in inflation. After 1980, a similar shock would have increased inflation in the industrial economies by only 3 percentage points. In the remainder of this subsection we extend this estimation to the largest possible sample of countries that the available data allow.

Specific details on the breakpoints and pass-through for each country are presented in Appendix 2, and the results of the statistical tests for each country are presented in Appendix 3. Of the 34 countries subjected to this method, only 7 showed no evidence of structural breaks.

Figure 2 shows the results of the estimation using endogenous windows calculated using the Bai-Perron structural break method. The figure plots averages for the countries in the sample. We show two estimations: one (the dotted line) uses data for all countries with available data at that point in time, out of the full sample of 34; the other (the solid line) uses only the 23 countries for which data are available for the whole period. Both series eliminate the top and bottom two observations. The figure shows a worldwide trend of falling pass-throughs. Conservatively (on the basis of the results for the fixed number of countries), we can say that the passthrough has fallen by more than six-sevenths, from the neighborhood of 14 percent to less than 2 percent.

A few additional results from the extended tables in the Appendices are worth highlighting. The first is that most industrial countries display significant falls in

\footnotetext{
${ }^{5}$ Hansen (2001) and Perron (2005) provide a review of the literature on structural breaks and we will only briefly discuss the main intuition that sustains the method that we apply. Estimation for multiple breaks was carried out using Matlab code based on the GAUSS code provided by Pierre Perron of Boston University at his web page http://people.bu.edu/perron/. Lag lengths for the right-hand variables were selected using the Hannan-Quin information criterion.
} 
their pass-through. In the case of United States, we find, as does Hooker (2002), a break in the early 1980s: the pass-through declines from 0.07 to 0.03 after 1981. We also obtain similar results for Canada as do Khalaf and Kichian (2003). In this case we find the fall in the pass-through to be from 0.05 to 0.02 .

Figure 2: Average Pass-Through over Time Using Endogenous Windows

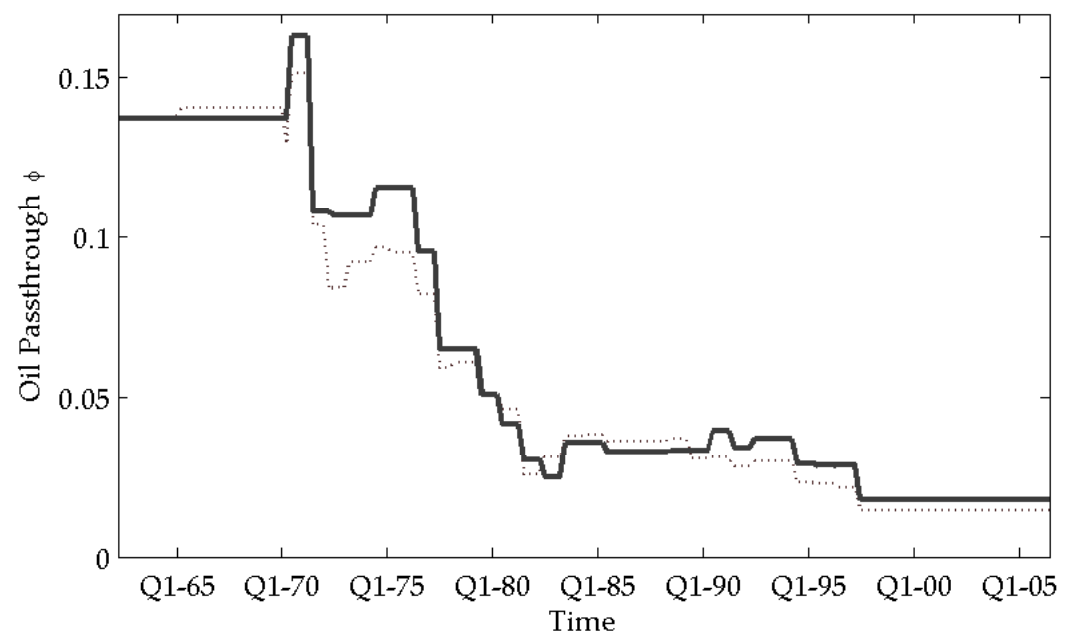

Source: Authors' calculations.

Note: Window lengths are endogenous since they are determined by the dates where we find evidence of a structural break. Pass-throughs were calculated for each section of the time series, and the average passthrough was calculated after eliminating the highest and lowest two observations.

The dark line represents a fixed group of countries that are always present in the sample, and the dotted line represents the average for those countries for which data were available for the indicated point in time.

A special case is Israel, which has been at center stage of many past oil shocks. Israel's pass-through has fluctuated dramatically, eventually falling to negative levels. It is very likely that, because Israel's macroeconomics (and politics for that matter) are so volatile, this Phillips curve methodology is not well suited to estimating the pass-through for this economy. The mildly negative pass-throughs of the African economies are also puzzling; again, however, it is probably safe to say that the pass-through has fallen in these countries during the last three decades, but the negative estimated pass-throughs suggest certain weaknesses of this methodology. Our emerging economies sample has several problems: it is small (as a result of data limitations), it includes oil producers (which do not normally encounter economic difficulties with oil price rises), and it includes several countries that have experienced severe high inflation and even hyperinflationary episodes, such as Argentina and Chile. In the case of Argentina, the hyperinflation of the early 1990s, coupled with the oil shock, tends to push the pass-through coefficient well above 1. Similarly, 
the period of highest inflation in Chile, which was unrelated to oil shocks and instead more related to fiscal imbalances and lax monetary policy, happened to coincide with the first oil shock. It seems clear that the assumptions required for these estimations to be valid are not present for some emerging economies. However, note that the final pass-through estimated for emerging economies reflects the global trend toward falling pass-throughs as more stable macroeconomic environments (more suitable for estimating Phillips curves) have prevailed. It is quite obvious that the estimated pass-through for these countries is reflecting other things beside oil shocks (credit crunches, balance of payment crises, etc.); these other factors may have coincided with oil shocks but were only triggered by the ensuing global recessions.

\section{The Effects of Exchange Rates and Oil Usage}

One problem with estimating Phillips curves in a large sample of countries is the currency denomination of oil prices. It is quite natural to specify oil prices in dollars when estimating the Phillips curve for the United States. However, this might be a problem for the rest of the world, since significant fluctuations in oil prices usually are accompanied by important adjustments of the exchange rate. Nonetheless, dollar-based estimations provide a good starting point for investigating the global inflationary impact of increases in the oil price. In addition, oil prices enter into the Phillips curve mainly because they affect production costs. However, the world's oil intensity has changed over time, and it is helpful to control for changes in oil intensity across countries. In this section we undertake both corrections.

\subsection{Changes in Oil Intensity}

The first argument that comes to mind to explain both the low pass-through from increases in oil prices to inflation and the weak recessionary effects of the recent oil price surge is that the world economy has changed structurally since the oil shocks of the 1970s. The economic importance of oil has fallen as industrial economies have become more services oriented and as previous oil shocks have driven them to more energy-efficient technologies as well as more diversified energy consumption. As economies become less dependent on energy (and as fuels represent a smaller proportion of total costs), the effect of an oil shock of given size is smaller.

There is plenty of circumstantial evidence to support the energy efficiency thesis for the United States. For example, Peterson et al. (2006) show that both petroleum and natural gas consumption, measured in BTU (British thermal units) per unit of real GDP, have fallen by half in the United States. Simple calculations from British Petroleum official data sets on worldwide oil consumption show that, in 1965, the average U.S. citizen consumed 20.69 barrels of crude oil, and that by 2005 this number had increased to 25.55 barrels. However, oil consumption per capita has grown by much less than GDP per capita, making U.S. GDP less oil intensive. In 
1965 it took 1,338 barrels of crude to produce \$1 billion of U.S. GDP (in 2000 dollars), but in 2005 it took only 753 barrels, or 44 percent less.

Figure 3: Oil Intensity in Selected Economies

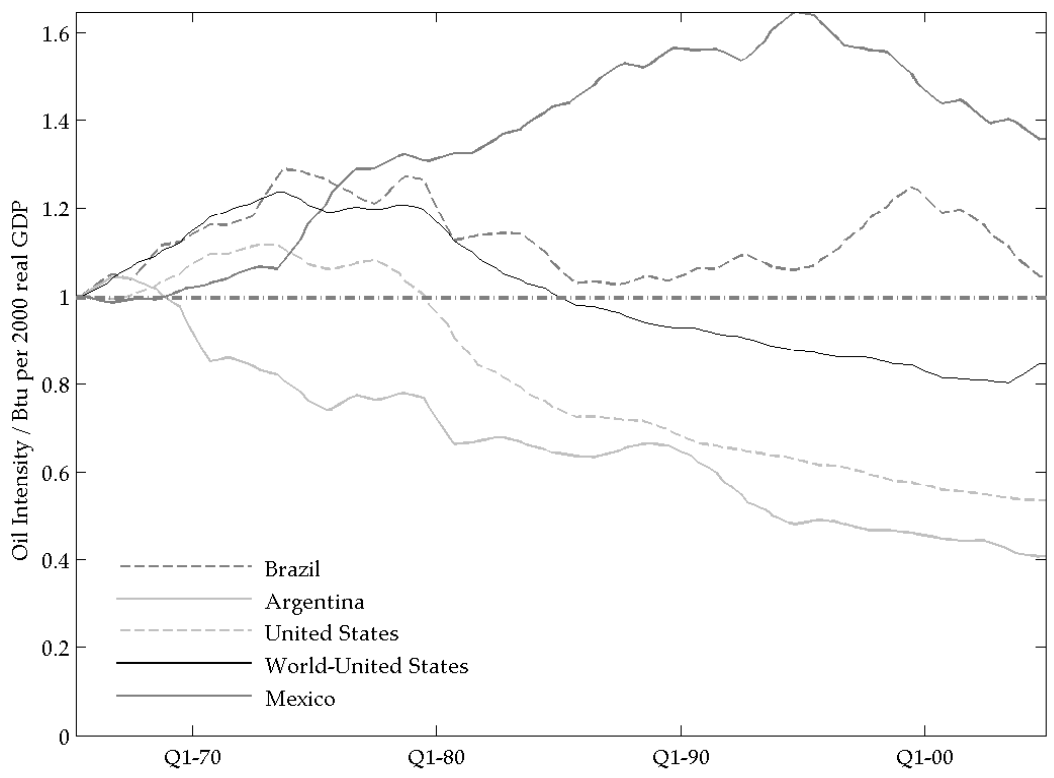

Source: U.S. Energy Information Administration.

Note: Oil intensity has been normalized by setting 1960 oil intensity equal to 1.0 .

However, not all countries have achieved an equivalent reduction in oil intensity. Figure 3 compares the evolution of oil intensity in the United States with that of the major Latin American economies and the rest of the world. Argentina has followed a similar process as the United States, sharply reducing its oil intensity. Brazil, on the other hand, has maintained its oil intensity roughly constant, and Mexico has increased its oil intensity. Mexico, of course, is an important oil producer, and hence its rise in oil intensity is easy to rationalize.

To get a broader sense of how differently oil intensity has evolved in different countries of the world, Figure 4 plots ratios of oil consumption to real GDP for a set of 45 countries for 1965 and 2004. The 45-degree line sets off those countries that have increased their oil dependency (those above the line) from those that have reduced it. The line at 22.5 degrees further separates those countries that, like the United States, have reduced oil dependency by half or more (those below the line) from the rest. 
Figure 4: Importance of Oil and Energy in the Economy

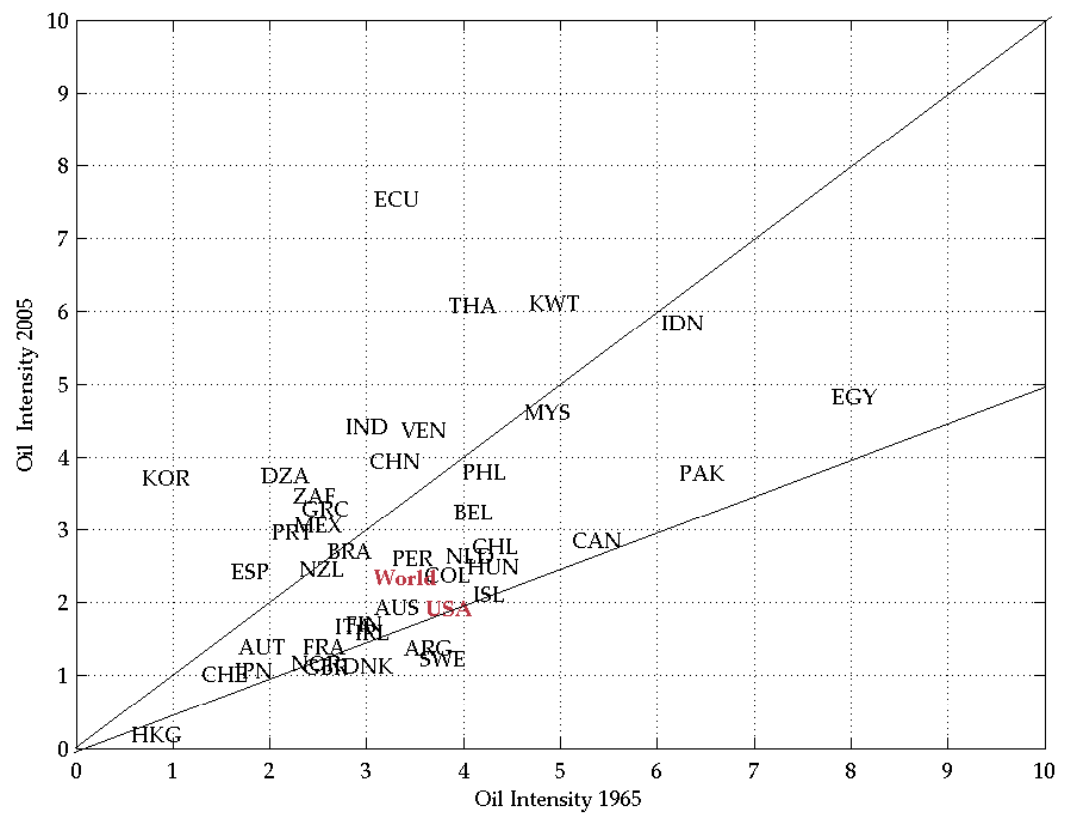

Source: International Financial Statistics and U.S. Energy Information Administration.

Figure 4 confirms that most countries have reduced their oil intensity, and that most of those that have increased their intensity are oil producers. The United States has experienced one of the largest declines. Given that the United States accounts for about 30 percent of world output, its reduction in intensity has driven world oil intensity down. On average, however, world oil intensity has fallen only 27 percent, or somewhat less than the decline in the industrial countries as a group. In general, we find that oil intensity has fallen in many countries, but not uniformly. The United States is not a representative case, although given its importance in the world economy it helps to explain why there have not been significant global repercussions, in terms of higher inflation and lower output, as a consequence of the sharp and persistent increase in the price of oil.

A fall in oil intensity can be caused by substitution to other energy sources or by a fall in the total energy needed to produce a unit of GDP. Figure 5 plots, on the y-axis, the ratio of oil intensity (barrels of oil per unit of real GDP) in 2004 to that in 1980. Numbers exceeding 1 thus indicate an increase in oil intensity. The $\mathrm{x}$-axis similarly plots the ratio of the energy efficiency index (BTUs of energy per unit of real GDP) in 2004 to that in 1980. Once again we find that the United States has reduced its energy use and has not substituted other energy for oil to any substantial degree (it is close to the 45-degree line, and hence both energy 
and oil consumption have declined somewhat proportionally), but that not every country has done likewise. Most of the countries in the sample (which overrepresents industrial countries) have become both less oil and less energy intensive. Countries below the 45-degree line have substituted away from oil to other fuel sources. Most of the industrial economies are slightly below the 45-degree line, indicating that some mild substitution has occurred. However, many of the emerging economies in our sample have actually increased their energy intensity, perhaps because they have attracted energy-intensive industries from the industrial world.

Figure 5: Importance of Oil and Energy in the Economy

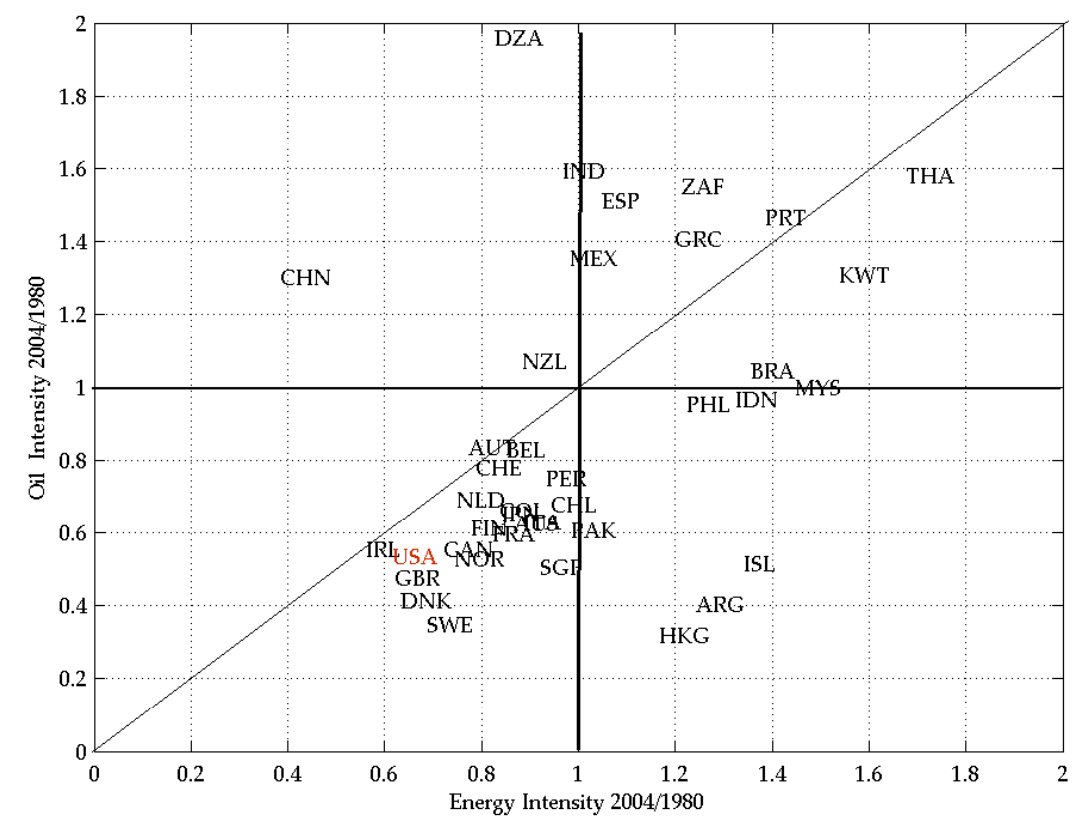

Source: International Financial Statistics and U.S. Energy Information Administration.

\subsection{Re-estimations of the Phillips Curve}

In this subsection we revise Phillips curve estimates in two different ways. We start by measuring world oil prices in domestic currencies and thus, we combine the passthrough of changes in oil prices, in dollars, with the pass-through of changes in exchange rates to inflation. Figure 6 presents the estimated average pass-through using the following specification of the Phillips curve:

$$
\pi_{t}=\alpha+\sum_{i=1}^{4} \beta_{i} \pi_{t-i}+\sum_{i=0}^{4} \gamma_{i}\left(y_{t-i}-\bar{y}_{t-i}\right)+\sum_{i=0}^{4} \theta_{i} \mathrm{oil}_{t-i}^{l o \$}
$$


where the only difference with equation (1) is that the oil ${ }^{l o \$}$ is the quarterly percentage change in the price of a barrel of Brent in local currency. As the figure shows, the sharp fall in the pass-through in the late 1970s survives this alternative specification, and the estimates of the pass-through in the last couple of decades are similar. What is different is that the pass-through estimates for the 1970s are much smaller, almost half of what they were in the earlier analysis. In this case the pass-through declines from 0.07 to 0.01 . This evidence suggests that almost half of the inflationary effect of the oil shocks of the 1970s was due to oil-induced devaluations rather than a direct effect of the increase in world oil prices.

Figure 6: Average Passthrough in Time: Endogenous Windows using Oil in Local Currency

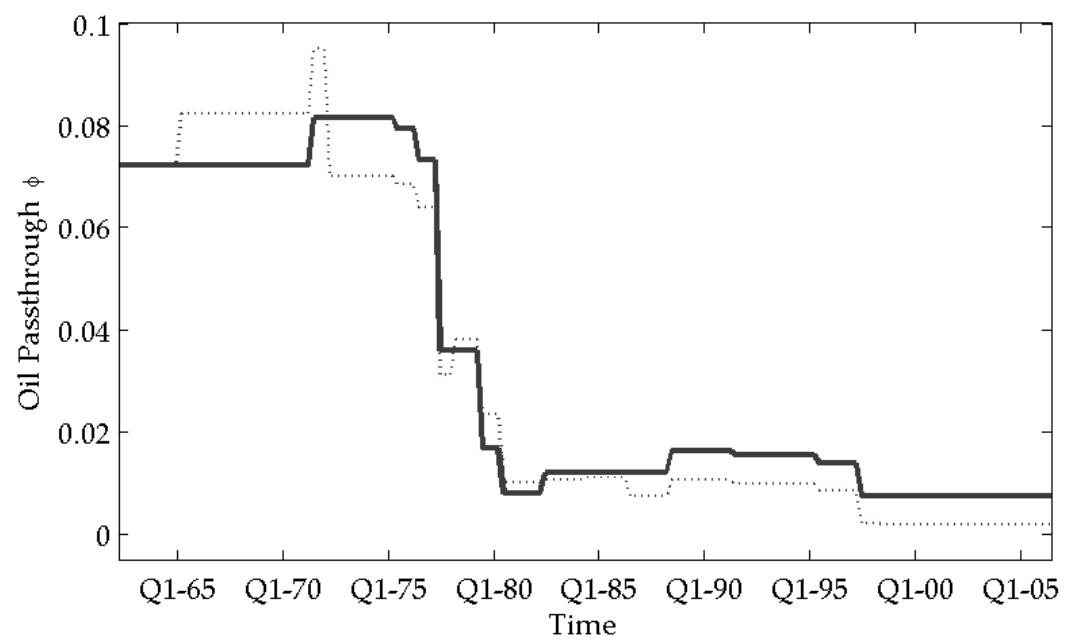

Source: Authors' calculations.

Note: Window lengths are endogenous as in Figure 2. The pass-through has been calculated using the specification in equation (3), where the percentage change in the oil price has been calculated in terms of local currency.

The darker line represents a fixed group of countries that are always present in the sample, and the dotted line the for those countries for which data were available from the indicated point in time.

The second correction to our estimations is to control for the changes in the importance of oil in each economy. ${ }^{6}$ We reestimate structural breaks and calculate the average pass-through using the following specification for the Phillips curve:

$$
\pi_{t}=\alpha+\sum_{i=1}^{4} \beta_{i} \pi_{t-i}+\sum_{i=0}^{4} \gamma_{i}\left(y_{t-i}-\bar{y}_{t-i}\right)+\sum_{i=0}^{4} \theta_{i}\left(\omega_{t} \cdot \mathrm{oil}_{t-i}^{u s \$}\right)
$$

\footnotetext{
${ }^{6}$ Hooker (2002) also controls for changes in the level of oil intensity of the U.S. economy. His results remain similar with this new specification.
} 
where $\omega_{t}$ is the oil intensity of the economy, normalized to 1 at the start of the series and defined as the amount of oil (in barrels) consumed per unit of real GDP. The average pass-throughs are presented in Figure 7. The lighter line represents the simple pass-through, and the darker one the average pass-through times the average oil intensity across economies. Thus the darker line combines both the decline in the effective pass-through from the oil price in domestic currency and the decline in oil intensity. The unadjusted pass-through falls from 0.04 to 0.025 , but when the oil price is adjusted for oil intensity, the decline is as low as 0.014. The difference is relatively constant since the early 1980s. The early 1970s show a slight increase in oil intensity, which explains the increasing pass-through adjusted by oil use.

Figure 7: Average Passthrough in Time: Endogenous Windows using Oil in Local Currency and by Oil Intensity

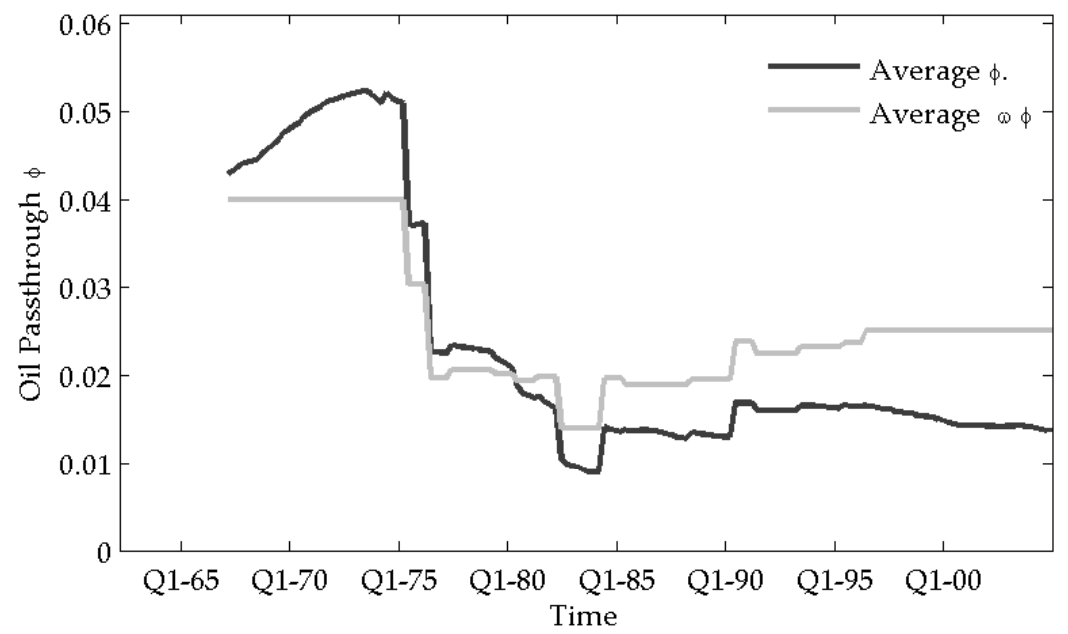

Source: Authors' calculations.

Note: Window lengths are endogenous as in Figure 2. The pass-through has been calculated using the specification in equation (4) where the percentage change in the price of oil has been multiplied by oil intensity. Both lines are averages for the group of countries that are always present in the sample; the lighter line shows the evolution of the coefficient of $\phi$ and the darker line the value of $\phi$ times the average intensity of oil.

From these figures we can conclude that two important factors in the decline of the effect of oil prices on inflation have been a decline in the use of oil per unit of GDP, and a decline in the impact of exchange rate changes on inflation. Even after adjusting for these two factors, however, a significant decline in the impact of increasing oil prices on inflation remains. In what follows we check these results using an alternative empirical approach, and we examine other factors that may have contributed to the decline in the oil pass-through. 


\section{Oil Shocks and VARs}

The estimation of Phillips curves provides persuasive evidence on the decline of the oil price pass-through, but we want to check the robustness of the results using a more theory-free empirical analysis, while taking into account the interactions of the different variables. Indeed, digging into the details on a country-by-country basis, we find some results that are difficult to explain, which are to a large extent the result of difficulties in estimating Phillips curves across countries. Therefore, to strengthen the evidence on the decline in the pass-through, in this section we use a different methodology to address the same issue. We attempt, using VARs, an estimation that involves a clearer identification of the interaction of different economic variables. Unfortunately, this methodology requires higher-frequency data and more variables, forcing a dramatic sacrifice in sample size.

The VARs are estimated for rolling windows of data starting between 1960 and 1974, depending on data availability. The methodology follows that of Wong (2000), which uses rolling VARs to argue that the effectiveness of monetary policy has fallen in the United States. However, our interest is in the orthogonalized impulse response of the CPI to an oil price shock. Our hypothesis will be that the impact of oil shocks has fallen as the rolling windows move closer to the present. In this case the measure of the pass-through will be the integral of the impulse response function for the VARs in each window. We will inquire whether these integrals have fallen over time.

The main advantage of the rolling VAR methodology is that it is an unstructured way of analyzing parameter changes and instability over time. The main handicap, as already noted, is that it requires more data: higher frequency for lags and more variables for the structure of the model. Given these data limitations, we try to approximate the best benchmark model, bearing in mind that our aim is not to investigate VAR modeling or inflation modeling as such, but rather to observe the changing effects of oil shocks given the model. Again, for the purpose of comparability across countries, we will sacrifice optimization of the fit of the model by not including dummies or controlling for country-specific factors.

\subsection{Methodology}

Since the nature of oil shocks has changed over time, using the triangular decomposition in the VARs is particularly critical. For example, pass-throughs may be constant over time, but the intensity of oil shocks may change. A Cholesky decomposition mixes these two elements of the effect of an orthogonal shock, since it consists of calculating the relative response of endogenous variables to orthogonalized shocks. This is why Cholesky impulse response functions are reported in terms of standard deviations of the shock. As a consequence, although we can determine whether the shock has statistically significant dynamic effects, we do not know whether those effects are of economic importance. Moreover, we cannot properly compare impulse responses across different windows in time, since it is perfectly plausible that the intensity of orthogonalized shocks has varied over time. In section 
2 we reported some differences in the intensity and length of the fluctuations of oil prices during the five potential shocks in the postwar period that we have analyzed. The 1973 Yom Kippur shock seems to have been the most intense, but the shocks since then have varied in length. When we estimate pass-throughs using the triangular decomposition, we can observe and compare the economic importance of these shocks.

Data limitations substantially limit our sample to only nine industrial economies (Canada, Denmark, France, Germany, Italy, Korea, Japan, the United Kingdom, and the United States) and three emerging economies (Colombia and Chile, which are the countries with the longest comparable series in Latin America, and Israel, which is always difficult to interpret).

\subsubsection{Impulse response functions and rolling windows.}

We estimate a VAR model by ordinary least squares (OLS). Because we use rolling windows of data, a slightly different approach must be taken in calculating the impulse response functions if we want to compare them through time. ${ }^{7}$ All estimations are in levels and include a time trend. The general system is the following:

$$
y_{t}=c+\beta_{t} t \sum_{i=1}^{p} \Phi_{i} y_{t-i}+\epsilon_{t},
$$

where $y$ is the vector of variables of the VAR, with $\epsilon \sim N(0, \Omega)$. Estimating $\hat{\Phi}, \hat{\Omega}$ by OLS, the MA representation can be written as

$$
y_{t}=\widehat{\mu}+\epsilon_{t}+\widehat{\Psi}_{t-1} \epsilon_{t-1}+\ldots
$$

The object of interest is the amount by which we must revise our forecast of the CPI $\left(y_{C P I}\right)$ given new information on the price of oil $\left(y_{o i l}\right)$ :

$$
\frac{\partial \mathrm{E}\left(y_{\mathrm{CPI}, t+s} \mid y_{t}\right)}{\partial y_{\mathrm{oil}, t}} \quad \forall s=1,2, \ldots \text { horizon }
$$

Given an oil shock, $\epsilon_{\mathrm{oil}, t}>0$, we can revise our estimate for the other shocks by using the information contained in $\widehat{\Omega}=T^{-1} \sum_{i=1}^{T} \hat{\epsilon}_{t} \hat{\epsilon}_{t}^{\prime}$. Concretely, we want to find how a unit change in $y_{\mathrm{oil}, t}=\epsilon_{\mathrm{oil}, t}$ leads to changes in the vector of innovations $\epsilon$, and to use this information, together with the $\Psi_{t+s}$ for each $s$ for the relevant horizon to determine by how much we should revise our forecast for the CPI given $y_{t}, \epsilon_{t}$.

We use the triangular decomposition $\Omega=A D A^{\prime}$ where $A$ is lower triangle and $D$ is a diagonal matrix giving the variance of $u_{t}=A^{-1} \epsilon_{t}$, where $u_{j t}$ (jidentifies a variable in the VAR and $-j$ the other variables other than $j$ ) is the residual projection of $\epsilon_{j, t}$ on $u_{-j, t}$ and so has the interpretation of new information about $y_{j, t}$ beyond that contained in $y_{-j, t}$. The effect of $\epsilon_{j, t}$ on $\epsilon_{t}$ is given by the the column

\footnotetext{
${ }^{7}$ See Hamilton $(1994,11.4)$ for details.
} 
$j$ of matrix $A$ denoted by $a_{j}$ and in our specific case correspondes to the column $A_{\text {oil }}$. In this way the orthogonalized impulse response function is given by the following expression:

$$
\frac{\partial \mathrm{E}\left(y_{\mathrm{CPI}, t+s} \mid y_{t}\right)}{\partial y_{\mathrm{oil}, t}}=\Psi_{s} A_{\mathrm{oil}} \quad \forall s=1 \ldots \text { horizon }
$$

We use the triangular decomposition instead of the more popular Choleski decomposition so as to isolate the estimated variance of the variable being shocked.

The Choleski decomposition is the following:

$$
\Omega=A D A=A D^{1 / 2} D^{1 / 2} A^{\prime}=P P^{\prime}
$$

In this case the impulse response function is given by

$$
\frac{\partial \mathrm{E}\left(y_{\mathrm{CPI}, t+s} \mid y_{t}\right)}{\partial y_{\mathrm{oil}, t}}=\Psi_{s} A_{\mathrm{oil}} \sqrt{d_{\mathrm{oil}}} \quad \forall s=1 \ldots \text { horizon }
$$

where $d_{\text {oil }}$ is the element along the diagonal of $D$ corresponding to the orthogonalized variance of oils price.

Under the Choleski decomposition, both $\widehat{\Phi}$ and $\widehat{\Omega}$ are functions of the data of each particular window so that the simulated $\widehat{\Psi}$ and $\widehat{A}, \widehat{D}$ will change when the estimated window changes. The impulse response functions will also change in response to variations in $\widehat{\Phi}, \widehat{A}$ and $\widehat{D}$. Hence, comparing them could be misleading since a fall in level could be due to a fall in the size of the shock $\sqrt{d_{\mathrm{oil}}}$. Instead, by using the triangular decomposition, we can interpret equation (8) as the consequence for the $\log$ of the CPI of a one-unit rise in the log of the price of oil.

\subsubsection{The model and variables}

In the general case for non-U.S. countries, the variables used are those suggested by Kim and Roubini (2000), that is, the log of the price of Brent crude in U.S. dollars, the U.S. federal funds rate, the log of the industrial production index, the log of the CPI, the log of M1, short-term interest rates, and the log of the exchange rate to the dollar. A time trend is also added. The model for the U.S. economy follows the work of (Wong 2000) and Bernanke and Mihov (1995) and includes the log of the price of Brent, the log of the industrial production index, the log of the CPI, the federal funds rate, the log of total reserves, and the log of nonborrowed reserves. ${ }^{8}$

We deliberately do not impose any structure on the VARs, and we use a set of variables and an ordering that are as conventional as possible. We do this in order to focus on the evolution of the estimates over time and to permit international comparability, rather than focus on the specifics of VAR estimation for each country. Caution should be used in interpreting the regressions and impulse response functions for France, Germany, and Italy, since those countries transited to a monetary union within the sample period.

\footnotetext{
${ }^{8}$ Three lags were chosen by Hannan-Quin information criteria for the United States and were used in all specifications for comparability.
} 


\subsection{Results}

The results of the VAR estimations are summarized in Figure 8, which shows the integrals of the 24-month impulse response functions for all the VARs estimated for each country on rolling windows of 200 months. ${ }^{9}$

Figure 8 seems to provide additional evidence of a decline in the pass-through. All of the countries in the sample show reductions in the pass-through up to the turn of the century. Interestingly, the United States displays the same increase in the pass-through up to the 1980s that it showed with the Phillips curve methodology. Chile and Colombia now show very clear reductions in the pass-through, and Korea and Japan show small but positive effects of oil shocks on inflation in the most recent VARs.

Nonetheless, there seems to have been a recent recovery in the pass-through in some countries, in particular Canada and the United States. On the other hand, Chile, Denmark, Israel, Japan, and Korea seem to have stabilized the pass-through at low levels. As we argued in the introduction, if the recent oil shocks were expected to be transitory, the pass-through should be low. If this rationalization of passthrough fluctuations has any merit, we should expect the pass-through to increase as the oil shock persists and more data are included. However, we do not see any systematic increase in the pass-through, an issue to which we will return in the next section.

Another interesting feature of these estimations is that they seem to indicate larger falls in the pass-through than we found in the previous section. Unfortunately, because of data constraints, both procedures cannot be applied to all countries, nor are the time frames necessarily the same. In addition, the estimations in this section include all of the possible feedback effects that could help dampen the impact of the hike in oil prices on inflation. In any case there are interesting contrasts with the estimations of the previous section. For example, Denmark was included in the database used in section 3, but we could not find a significant breakpoint. In contrast, in this section we find clear evidence of a fall in the Danish pass-through, when the data from the early 1970s are excluded from the estimation window.

For the countries that are included in both exercises, it is probably best to compare the relative changes in the pass-through that the two methodologies generate rather than the specific parameters estimated. In section 3 the estimated pass-through coefficient corresponds to the permanent effect of a 1 percent increase in the oil price on inflation, and here we are estimating the impact of a one-unit change in the log of the oil price, so the shocks are approximately comparable.In comparing the results of this section with those of the previous one, it is probably best to look at the final months of the 24-month impulse response functions as an approximation of the permanent effect of the shock on inflation. Also, recalling that the units of the impulse response functions are the logs of the monthly CPI, to make them comparable we have to (approximately) multiply by 12 . Hence, whereas the

\footnotetext{
${ }^{9}$ These models were also estimated with different window sizes (190 and 210 months), with similar results. The whole surface of impulse response functions are presented in Appendix 4.
} 
previous section shows the U.S. pass-through falling from 7 percent to 3 percent, here the decline is from 60 percent to 6 percent, a much greater fall. For Canada, our previous calculations show a fall from about 5 percent to about 2 percent, and our new calculations show a fall from about 3.5 percent to about 0.5 percent, which is also a sharper decline. In general, our VARs indicate a much greater fall in the pass-through than our Phillips curve estimations.

Figure 8: Accumulated Effect of a Unit Oil Shock on Inflation (shock measured as 1 U.S.\$)
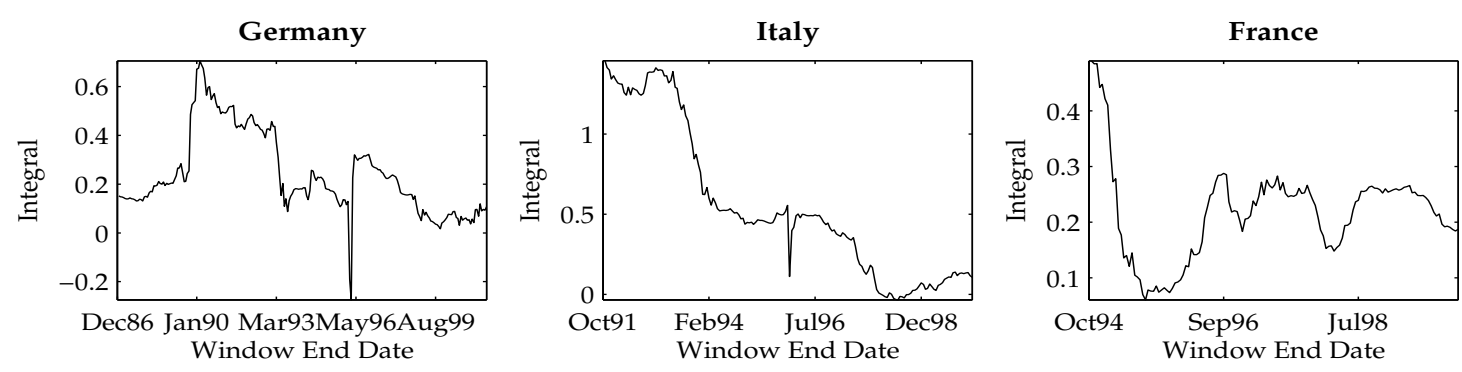

Denmark

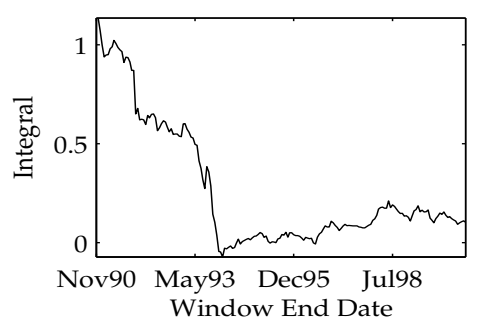

Chile

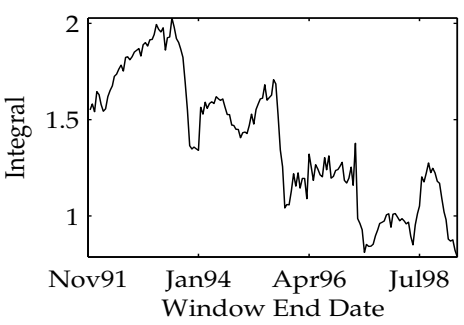

Colombia

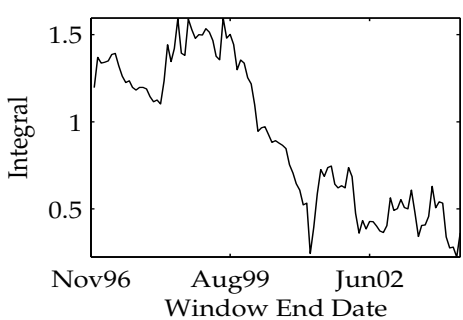

Japan

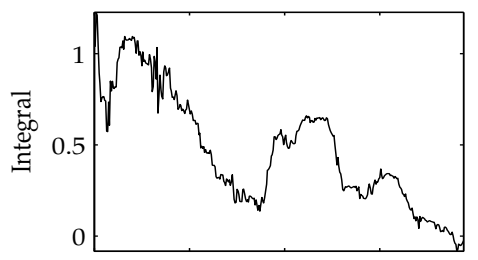

Nov73 May79 Sep84 Jan90

Window End Date
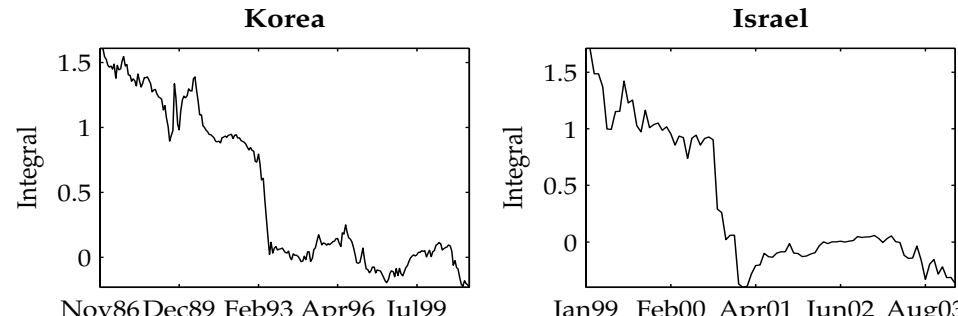

Window End Date

Window End Date
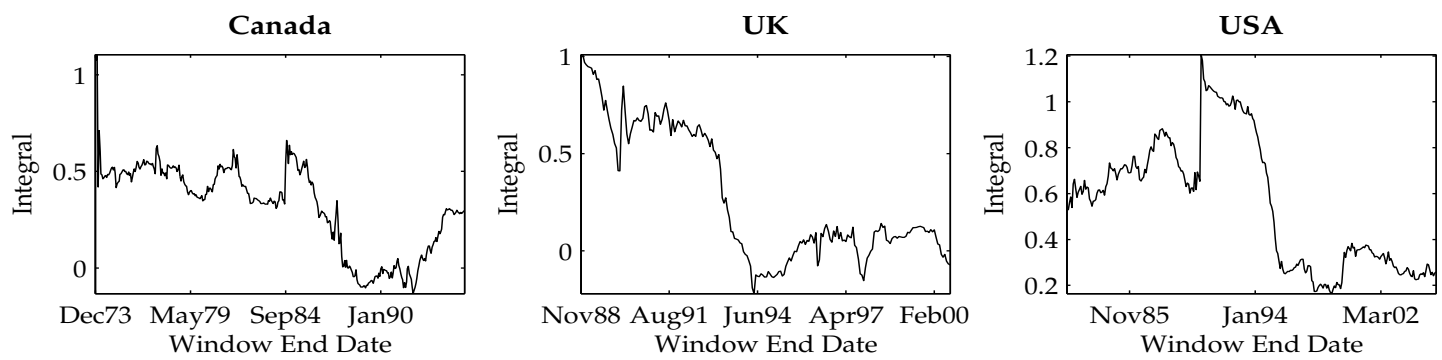

Source: Authors' calculations.

The accumulated effect is calculated as the integral of the impulse response function for a 24 month horizon.

The window width is 200 months. 
However, the estimations of the decline in the pass-through found in this section combine all the indirect effects stemming from movements in other variables. In particular, both the decline in the exchange rate pass-through and the reaction of monetary policy should be included in the final effect, although oil prices are measured in U.S. dollars. Finally, and to highlight the differences between the two econometric approaches, we are able to find a reasonable estimate for the fall in the Chilean pass-through, whereas in the previous section we could not.

\section{Explanations for the Decline in the Oil Pass-Through}

So far we have documented a generalized decline in the oil pass-through for a large number of economies. To do this we have used two alternative statistical methodologies, which seem to consistently show a significant reduction in the effect of oil price changes on inflation in industrial as well as in emerging economies. We have also found that part of the decline in the pass-through is due to a decline in the effect of exchange rate changes on inflation and to a reduction in oil intensity. But even after taking both these factors into consideration, part of the decline in the impact of oil prices on inflation remains in need of further explanation. In this section we discuss additional factors that might explain this residual decline and how these factors can also help explain the reduced impact of the recent oil price increase on world economic activity.

\subsection{The Nature of Oil Shocks (Supply versus Demand) and the Role of Exchange Rate Movements}

In recent discussions of the modest impact of oil prices on world activity, an important explanation has been the nature of the shock. Whereas in previous shocks the driving force was supply shortages, today, it is argued, the rise in the oil price has to a large extent been driven by demand (mainly U.S. and Chinese demand, coupled with speculation by hedge funds).

This explanation is relevant not only for oil-importing countries but for commodityexporting countries as well. The global increase in demand for commodities means that the output effects of recent oil shocks should be less pronounced for commodity exporters. In contrast, if the rise in prices is caused by supply constraints, the effect on all oil-importing countries will be the same no matter their export structure. Therefore the fact that the recent oil shock has been a demand rather than a supply shock has important macroeconomic implications. However, to explain the limited inflationary effects, we need to identify additional mechanisms associated with the demand shock, especially given that greater economic activity should induce inflationary pressures. Here is where the effects of the evolution of the exchange rate become relevant. Note that this is a different issue than the decline in the pass-through. The point we make here is that there has been much less currency 
depreciation than in previous oil shocks.

An expansion of demand for all commodities, rather than just oil, generates an appreciation in the currencies of commodity-exporting countries, which offsets the impact of world oil prices in these countries and makes the shock milder in terms of domestic currency. Supply-driven oil shocks, on the other hand, are not accompanied by the same offsetting effect on the exchange rate. ${ }^{10}$

Figure 9: Oil Price Changes in Domestic and Foreign Currency

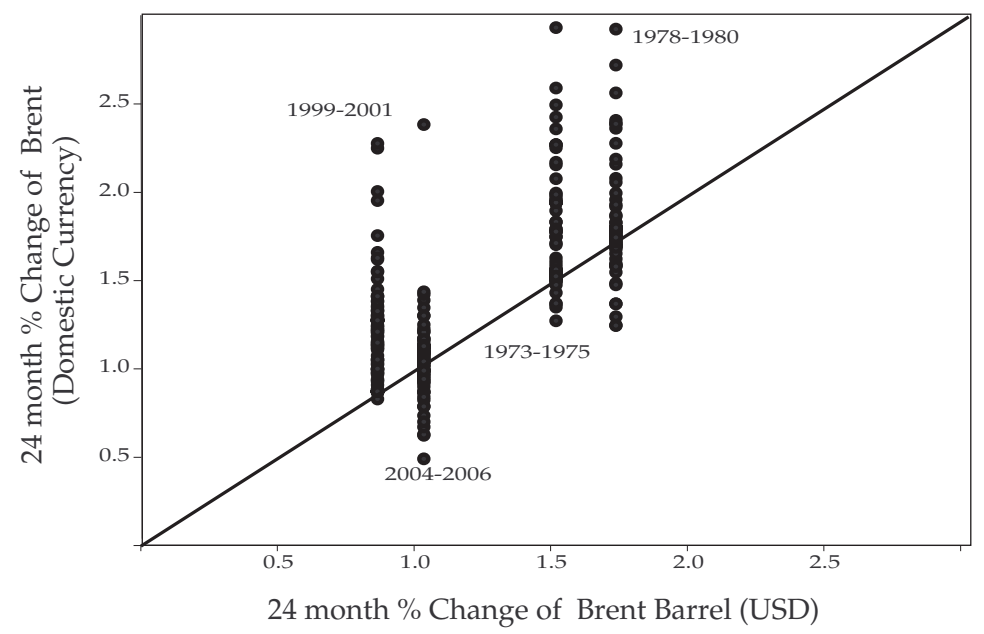

Source: International Financial Statistics and U.S. Energy Information Administration.

Figure 9 plots the change in oil prices in U.S. dollars against the same change in domestic currencies for 163 countries during each of the four shocks we have identified. The figure shows that there can be some significant differences in the intensity of oil price shocks depending on the currency denomination. If these differences were not very important, one would expect most of the observations in the chart to lie on or near the 45-degree line. However, there are important deviations. It is quite interesting that the three earlier oil shocks were accompanied, in general, by depreciations, which made them more inflationary in domestic-currency terms: most of the points are above the 45-degree line, indicating that the domestic currency shock has been larger then the U.S. dollar shock. In contrast, in the most recent oil shock, a substantial number of countries have experienced an appreciation, which has softened the shock. This shows that the nature of the shock matters, and it

\footnotetext{
${ }^{10}$ Kilian (2006) explores the distinction further by distinguishing increases in the demand for oil stemming from strong global demand, which should impact all commodities, from demand increases for oil specifically, for example due to fears of future shortages. In our discussion the latter should be similar to a supply shock in terms of its inflationary consequences.
} 
allows one to explain the compensatory movements of the exchange rate as well as the reduced impact of the oil price hike on economic activity.

Finally, we can also look at the combination of oil shock pass-throughs and exchange rate fluctuations. If, as a consequence of a supply-driven oil shock, a country also suffers a depreciation, the prices of goods other than oil could rise as a consequence, increasing the inflationary consequences of the oil shock. This could be aggravated by the fact that exchange rate pass-throughs were larger in the past. In the oil shock of 1999 to 2001, however, most currencies depreciated against the U.S. dollar, but the exchange rate pass-through had already declined.

\subsection{The Persistence of Oil Shocks}

The literature on exchange rate pass-through has attributed much of its recent decline to the presence of flexible exchange rates. More generally, Taylor (2000) has argued that low persistence of cost changes reduces the pass-through from cost to prices, as price setters will be more reluctant to change their prices if there is an increased probability that a given cost rise will be reversed. This argument also applies to flexible exchange rates and the exchange rate pass-through. In contrast, under more rigid exchange rate systems, discrete changes in the exchange rate are unlikely to be reversed, and hence firms will be more prone to change their prices. In particular, when a depreciation occurs, there will be a greater incentive to do so. Hence the increased popularity of flexible exchange rate regimes could explain the fall in the pass-through from exchange rate fluctuations to inflation.

The same argument can also be applied to an oil shock: a smaller pass-through should be expected for a transitory oil shock than for a more persistent shock. This may be what happened with the 1991 and 1999 oil shocks. However, the current oil shock has lasted much longer than the previous ones (see Figure 1), and thus the explanation based on transitory versus permanent shocks is not sufficient, since pass-throughs remain low.

The issue is in fact somewhat more subtle: the question is how persistent a given oil shock is expected to be, rather than how long it ends up being. One could argue that the most recent shock has been surprisingly persistent, whereas the previous ones, for which the pass-through was higher, were unexpectedly short lived. Of course, it is necessary to explain these wrong perceptions, but we can still go to the data to look at the perceived persistence.

A simple way to address this issue is to look at prices of oil futures. Figure 10 shows the evolution of the spot price of Brent since 1995; the expected evolution of the Brent price as indicated by futures contracts is also shown at various points in the series. It is quite clear that, up to the later months of 2004, the market still acted as if the shock were partly transitory, as previous shocks had been.

More recently, however, futures contracts are increasingly reflecting the high persistence of the shock: the lines representing the most recent futures contracts are substantially flatter than the previous ones. Therefore the current oil shock 
not only has been more persistent, but is also increasingly perceived to be so, yet the pass-through has declined instead of increasing as the Taylor hypothesis would suggest. Although the exchange rate pass-through is not determined by the same fundamentals as the oil pass-through, the persistence hypothesis should hold for both. Looking at the impact of the oil shock on inflation thus calls the persistence argument into question.

Figure 10: Oil Brent Price and Oil Futures

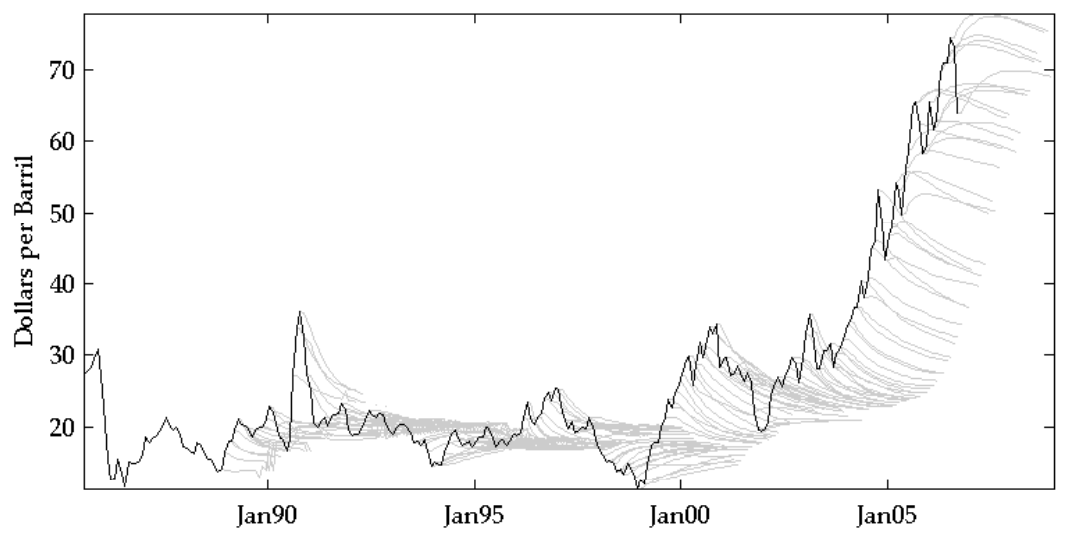

Source: Bloomberg

\subsection{Domestic Regulation of Oil Markets}

We have not yet explored the possibility that, as a result of previous oil shocks, domestic oil markets have become more regulated and thus better able to buffer oil shocks. According to this hypothesis, countries may have implemented institutional or de facto price stabilization mechanisms such as countercyclical oil taxes, stabilization funds, or countercyclical administration of strategic oil reserves. In that case oil prices at the pump would not reflect the volatility of international oil prices. Verification of this hypothesis requires finding consistent data sets of oil pump prices for an important group of countries, for a long period of time, and these are very difficult to come by. Figure 11 shows the evolution of the retail price of regular gasoline in the United States and of the wholesale Brent price on international markets. Both series move very much in tandem. At least in the United States, there seems to be little evidence that the domestic pump price is being substantially smoothed with respect to the wholesale price. 
Figure 11: Regular Gasoline U.S. City Average Retail Price Including Taxes (EIA)

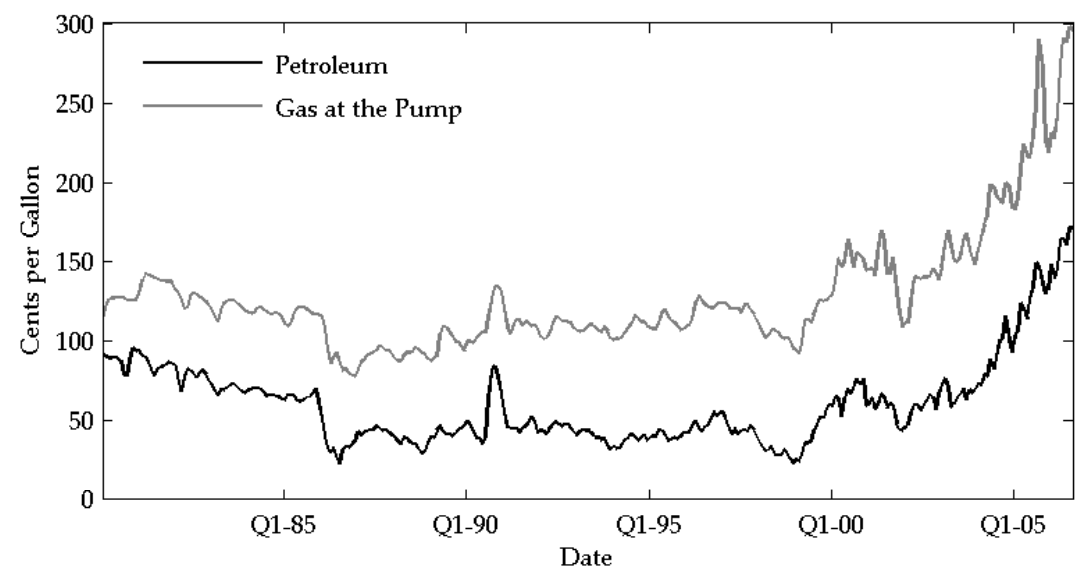

Source: Bloomberg

It is reasonable to expect that domestic oil pump prices will be, in general, more stable than wholesale prices. But anecdotal evidence does not seem to indicate that domestic stabilization mechanisms have led to any consistent deviation of oil pump prices from wholesale international prices in the countries we are analyzing. This is particularly important for the current shock, which, as we have seen, has been significantly more persistent than past shocks. Moreover, it seems that it is the oilexporting countries that tend to strongly subsidize their domestic oil prices, driving a wedge between wholesale and retail prices. It does not seem plausible, therefore, that domestic stabilization mechanisms - at least in these countries - have prevented domestic pump prices from following wholesale prices. In addition, serious attempts have been made in previous oil shocks to stabilize domestic gasoline prices-the Nixon price and wage controls are an important example.

Therefore the issue is not the direct pass-through from oil prices to domestic gasoline prices, but rather the second-round effects, that is, the transmission from oil and gasoline prices to other prices in the economy. The low observed passthroughs are the result of a decline in the transmission from higher domestic oil prices to prices in the rest of the economy.

\subsection{The Response of Monetary Policy to Oil Shocks}

Another possible explanation of the decline in the oil pass-through is that central banks have become more willing to fight inflation through monetary policy. Central banks around the world have become increasingly independent, with a clear mandate for price stability and, in several countries, the adoption of inflation targeting 
regimes. If a central bank is strongly committed to keeping inflation low and fights all supply shocks aggressively to achieve that objective, no change in inflation in response to large swings in oil prices will be observed in that country. As a corollary, the output effects of oil shocks should be larger, although this has not been the case in the current oil shock. One could argue, however, that aggressive central banks accrue a credibility bonus that allows them to anchor inflation at a lower output cost. We find merit in this argument, but we postpone discussion of it in order first to focus on interest rate fluctuations as a way of measuring the actual responsiveness of monetary policy to oil shocks.

The greater commitment to inflation could have increased the response of interest rates to inflation. Indeed, Clarida et al. (2000) estimate Taylor rules and find that interest rate policies were much more sensitive to inflation in the GreenspanVolcker era than previously. Taylor (2000) estimates that the coefficient of inflation in a Taylor rule estimation for the late 1980s is double what it was in the 1960s. Moreover, Bernanke et al. (1997) estimate a structural VAR specifically to identify the response of monetary policy to oil shocks. They find that the endogenous monetary response to oil shocks accounts for most of its effects on the economy.

However, Hooker (2002) argues that a reestimation of Bernanke et al.'s (1997) VAR for the post-1979 period shows a significant reduction in the response of monetary policy to oil shocks compared with the pre-1979 period. Leduc and Sill (2004) also split their sample in 1979 and find that, in the more recent sample, 40 percent of the decline in output in the United States due to oil shocks is caused by the reaction of the Federal Reserve, whereas in the older sample it is as much as 75 percent. These results do not contradict previous estimations of Taylor rules that show an increased reaction to inflation, since the VAR evidence to which we refer here consists of estimations of the reaction to a particular inflationary shock, namely, a rise in oil prices.

Summing up, there is no broad evidence that the reaction of monetary policy to oil shocks has increased. Such a reaction has occurred in only a few countries. However, in other countries the gain in credibility and the commitment to low inflation may have contributed to the reduction in the oil pass-through, as well as in the exchange rate pass-through, without the need for an increased reaction to oil price hikes. In addition, the fact that interest rates are today more responsive to inflation than before may better anchor the second-round effects from oil shocks, reducing their inflationary impact and consequently reducing the reaction from monetary policy.

\subsection{The Current Low Inflation Environment}

A related possible reason for the reduced impact of the oil shock on inflation is that the global decline of inflation has brought, via a number of mechanisms, a substantial reduction in the second-round effects of oil shocks.

A first and traditional explanation in the context of rigid prices, when these are 
caused for example by menu costs, is that when inflation is low, price changes are less frequent. When deciding prices, firms may postpone the reaction to oil shocks if inflation is low, since they adjust prices infrequently. When inflation is higher, firms are already regularly incurring the costs of changing prices, and so they can more rapidly build the oil shock into their prices. As a result, the oil pass-through should be larger in economies with higher inflation. Something similar has been found in the case of the exchange rate pass-through (Borensztein and De Gregorio 1999).

As an exploratory way of investigating the relationship between the level of inflation and pass-through, we use the results from section 5 and run a a fixed-effects panel regression between the average level of inflation during the window and the integrals of the impulse response functions of the oil price from a shock to inflation as shown plotted below by Figure 12. The upward-sloping line represents the result of a fixed-effects linear regression between the two series, which delivered a positive and significant slope. When we ran this regression for each country, all but one of the coefficients turned out to be positive, and more than half were significantly different from zero. These results support the idea that, in countries where inflation has declined, the impact of oil shocks on inflation has also declined. These results support the idea that, in countries where inflation has declined, the impact of oil shocks on inflation has also declined.

This evidence may also be consistent with the existence of a credibility bonus as mentioned before. As inflation expectations draw closer to the inflation objective, the incentives for price changes in response to supply shocks should be smaller.

Figure 12: Inflation levels and Pass-through

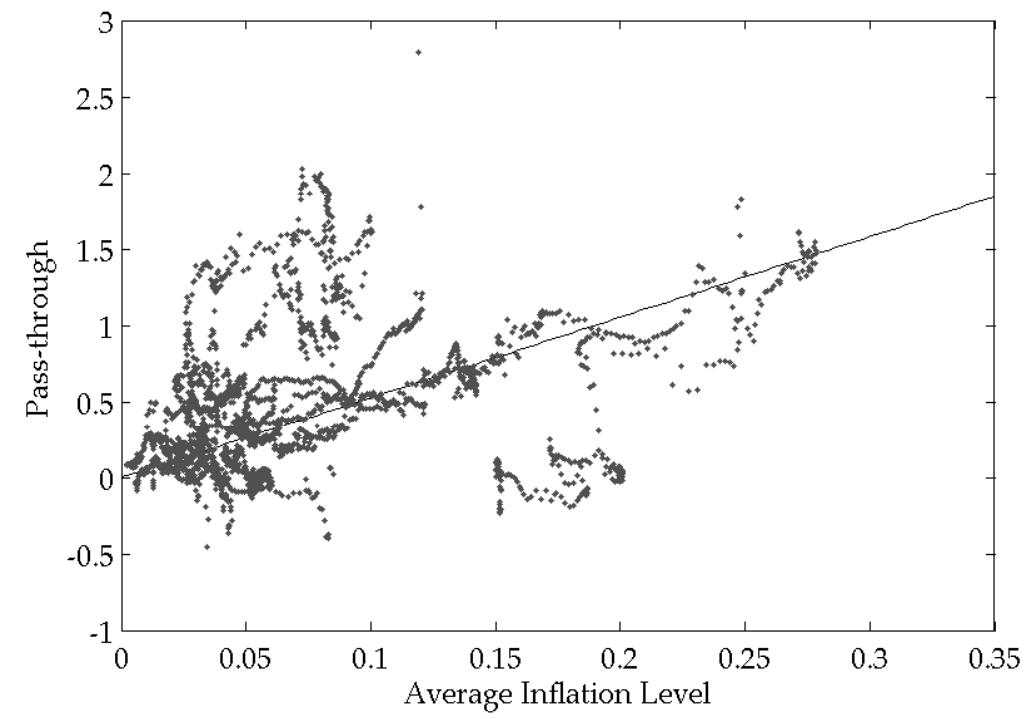

Source: Authors' calculations. 
More generally, it could be argued (although we present only circumstantial evidence) that the global decline in inflation has reduced the pass-through from oil prices to inflation. This could be due to a greater commitment to price stability, a credibility bonus, a reduced response of prices to supply shocks due to price rigidities, or even the increase in globalization as recently emphasized by Rogoff (2003). ${ }^{11}$ Whatever the reason, we cannot rule out that the impressive decline in the effect of the rise of oil prices on inflation is a result of the lower-inflation environment. This has also reduced the exchange rate pass-through, a factor that, as we showed in section 3 , has contributed in a relevant way to the reduction of the oil price impact.

\section{Conclusions}

This paper has presented evidence of a significant fall in the pass-through of oil price changes to general inflation in recent decades. We find that this is a generalized fact for a large set of countries. The paper began by documenting correlations between the CPI and oil prices and then used two estimation strategies to try to properly identify the effect of oil shocks on inflation. First, the traditional Phillips curve was augmented to include oil, and structural breaks were estimated for 34 countries. This methodology showed a clear fall in the average estimated pass-through for industrial economies and to a lesser degree for emerging economies. Even so, the pass-through estimates for the most recent periods in emerging markets seem much more reasonable and consistent with the results from industrial economies. The results hold when oil is valued in local currency, but the pass-through drops less when oil intensity is controlled for. In addition, when we controlled for oil intensity, we found that the decline in the economic intensity of oil use over the years helps to explain the limited impact of more recent oil shocks on inflation. Therefore we conclude that a significant part of the decline in the oil pass-through around the world is explained by the reduction in the effects of exchange rate changes on inflation and by declining oil intensity. However, our estimates show that, even after controlling for these factors, part of the decline in the oil pass-through remains unexplained.

Second, we estimated rolling VARs for a subsample of countries for which we have sufficient data. We derived impulse response functions of inflation to oil shocks and interpreted the integrals of these impulse responses as estimates of the passthrough. We find that the effect of oil shocks on inflation for a 24-month window has fallen for most of the 12 countries in the sample.

\footnotetext{
${ }^{11}$ For a discussion on second round effects of the recent oil shock in the U.K. economy, see Bean (2007).
} 
Next, we looked for additional potential explanations for the widely observed fall in the pass-through from oil prices to inflation. We examined a number of factors that could explain this decline but did not find strong evidence pointing to any single specific explanation. One promising additional explanation is the present lower-inflation environment, working perhaps through the manner in which monetary policy reacts to oil prices, or through some credibility bonus. A second is the demand-based nature of the current oil shock: because today's high oil prices are to a large extent due to strong world demand rather than supply shortfalls, movements in exchange rates have not reinforced the consequences of high world oil prices, as happened in previous episodes. In contrast to the literature on exchange rate pass-through, which predicts that persistent changes in costs should increase the pass-through, the current oil shock has been quite persistent, and perceived as highly persistent by the market, but the inflationary consequences have been moderate. Finally, we found no evidence that regulation of domestic gasoline markets, at least in the United States, has helped ameliorate the inflationary impact of high oil prices.

The reaction of the global economy to the recent oil shock has been very different from that in previous oil shocks. The world economy appears to be much more resilient than in previous episodes. Economic activity has suffered little in the current juncture, and inflation has remained under control. Indeed, most traditional estimates of the impact of oil on the economy have been scaled down to fit current developments. We believe our findings help explain this greater resilience. The decline in the oil intensity of economies reduces the inflation and output impacts of oil price hikes. In addition, the movements in exchange rates that accompany the oil shock have less inflationary consequences, and hence require a milder reaction from monetary policy-a factor that has been highly relevant in explaining previous slowdowns stemming from oil shocks. Finally, the high oil price in recent years has been the result of high demand rather than supply shortages as in the past. 


\section{References}

Bai, J. and P. Perron (1998), "Estimating and Testing Linear Models with Multiple Structural Changes," Econometrica, 66 (1): 47-78.

Bai, J. and P. Perron (2003), "Computation and analysis of multiple structural change models," Journal of Applied Econometrics 18 (1): 1-22.

Barsky, R. and L. Kilian (2004), "Oil and the Macroeconomy since the 1970s," Journal of Economic Perspectives, 18 (4): 115-134.

Bean, C. (2007), "Globalization and Inflation," World Economics, 8 (1): 57-73.

Bernanke, B., M. Gertler, and M. Watson (1997), "Systematic Monetary Policy and the Effects of Oil Price Shocks," Brookings Papers on Economic Activity, pp. 91-116.

Bernanke, B. and I. Mihov (1995), "Measuring Monetary Policy," NBER Working Papers 5145, Cambridge, Mass.: National Bureau of Economic Research.

Borensztein, E. and J. De Gregorio (1999), "Devaluation and Inflation after Currency Crises," Washington: International Monetary Fund.

Burstein, A., M. Eichenbaum and S. Rebelo (2005), "Large Devaluations and the Real Exchange Rate," Journal of Political Economy, 113(4): 742-783.

Campa, J. and L. Goldberg (2002), "Exchange Rate Pass-Through into Import Prices: A Macro or Micro Phenomenon?," NBER Working Papers 8934, Cambridge, Mass.: National Bureau of Economic Research.

Clarida, R. and J. Galí and M. Gertler (2000), "Monetary Policy Rules And Macroeconomic Stability: Evidence And Some Theory," The Quarterly Journal of Economics,115(1): 147-180.

Choudhri, E., and D. Hakura (2006), "Exchange Rate Pass-Through to Domestic Prices: Does the Inflationary Environment Matter?," Journal of International Money and Finance, 25(4): 614-639.

Davis, M. and J. Hamilton (2003), "Why Are Prices Sticky? The Dynamics of Wholesale Gasoline Prices," NBER Working Papers 9741, Cambridge, Mass.: National Bureau of Economic Research.

Frankel, J., D. Parsley, and S. Wei (2005), "Slow Passthrough Around the World: A New Import for Developing Countries?," NBER Working Papers 11199, Cambridge, Mass.: National Bureau of Economic Research. 
Gagnon, J. and J. Ihrig, (2001), "Monetary Policy and Exchange Rate PassThrough," International Finance Discussion Papers N704, Washington: Board of Governors of the Federal Reserve System.

Galí, J, M. Gertler and J. Lopez-Salido (2005), "Robustness of the Estimates of the Hybrid New Keynesian Phillips Curve," Journal of Monetary Economics, 52 (6): 1107-18.

Goldfajn, I. and S. Werlang (2000), "The Pass-Through from Depreciation to Inflation: A Panel Study," Textos para Discusso 423, Department of Economics PUC-Rio (Brazil).

Hamilton, J. (1994), Time Series Analysis, Princeton University Press.

Hamilton, J. and A. Herrera (2001), "Oil Shocks and Aggregate Macroeconomic Behavior: The Role of Monetary Policy," University of California at San Diego, Economics Working Paper Series 2001-10, Department of Economics, University of California, San Diego.

Hansen, B. (2001), "The New Econometrics of Structural Change: Dating Breaks in U.S. Labour Productivity," Journal of Economic Perspectives, 15 (4), 117-128.

Hooker, M. (2002), "Are Oil Shocks Inflationary? Asymmetric and Nonlinear Specifications versus Changes in Regime," Journal of Money, Credit and Banking, $34(2), 540-61$.

Khalaf, L. and M. Kichian (2003), "Testing the Stability of the Canadian Phillips Curve Using Exact Methods," Working Paper Bank 2003-7, Bank of Canada.

Kilian, L. (2006), "Not All Oil Price Shocks are Alike: Disentangling Demand and Supply Shocks in the Crude Oil Market," CEPR Discussion Paper No. 5994, London: Centre for Economic Policy Research.

Kim, S. and N. Roubini (2000), "Exchange Rate Anomalies in the Industrial Countries: A Solution with a Structural VAR Approach," Journal of Monetary Economics, 45 (3), 561-586.

Leduc, S. and K., Sill (2004), "A quantitative analysis of oil-price shocks, systematic monetary policy, and economic downturns," Journal of Monetary Economics, 51 (4), 781-808.

Mork, K. (1989), "Oil and Macroeconomy When Prices Go Up and Down: An Extension of Hamilton's Results," Journal of Political Economy, 97 (3): 74044 .

Perron, P. (2005), "Dealing with Structural Breaks," Boston University Working Papers Series in Macroeconomics WP2005-017, Department of Economics, Boston University. 
Peterson, J. and R. Farmer and M. Lasky and A. Mascaro and A.Weber (2006), "The Economic Effects of Recent Increases in Energy Prices," The Congressional Budget Office CBO Paper 2835.

Rogoff, K. (2003), "Globalization and global disinflation," Economic Review, Q $I V, 45-78$.

Rudd, J. and K. Whelan (2005), "Modelling inflation dynamics: a critical review of recent research," Working Paper 2005-66, Washington: Board of Governors of the Federal Reserve.

Taylor, J. (1998), , “An Historical Analysis of Monetary Policy Rules," NBER Working Papers 6768, Cambridge, Mass.: National Bureau of Economic Research.

Taylor, J. (2000), "Low Inflation, Pass-Through, and the Pricing Power of Firms," European Economic Review, 44 (7): 1389-1408.

Wong, K.-F. (2000), "Variability in the Effects of Monetary Policy on Economic Activity," Journal of Money, Credit and Banking, 32 (2): 179-98. 


\section{Appendices}

\section{Appendix 1 Data Description}

Table A2: Original Data Sources and Descriptions for the CPI by Country

\begin{tabular}{|c|c|c|}
\hline Countries & Series Dates Used & IFS Production Index Description \\
\hline Argentina & Q1-72 - Q4-05 & CONSUMER PRICES \\
\hline Australia & Q1-62 - Q2-06 & CPI:ALL GROUPS,SIX CAPITALS \\
\hline Austria & Q1-62 - Q1-06 & CPI 20 TOWNS \\
\hline Barbados & Q1-75 - Q1-06 & CPI:NATIONAL \\
\hline Belgium & Q1-62 - Q2-06 & CPI:ALL GROUPS,62 CENTERS \\
\hline Canada & Q1-62 - Q2-06 & CPI:ALL CITIES POP OVR.30,000 \\
\hline Chile & Q1-62 - Q1-06 & CPI:SANTIAGO-ALL INC \\
\hline Cote d'Ivoire & Q1-70 - Q1-06 & CPI:ABIDJAN:ALL ITEMS,AFR.FAM \\
\hline Denmark & Q1-62 - Q1-06 & CPI: 70 LOCALITIES \\
\hline Finland & Q1-62 - Q2-06 & CPI: ALL COUNTRY \\
\hline France & Q1-62 - Q1-06 & CPI: 108 CITIES \\
\hline Germany & Q1-72 - Q1-06 & CPI together \\
\hline Greece & Q1-62 - Q1-06 & CPI:URBAN AREAS \\
\hline India & Q1-62 - Q1-06 & CPI:INDUST.WORKERS,50 CENTERS \\
\hline Industrial countries & Q1-70 - Q2-06 & CPI \\
\hline Ireland & Q1-62 - Q2-06 & CPI: ALL ITEMS \\
\hline Israel & Q1-62 - Q1-06 & CPI URBAN FAMILIES \\
\hline Italy & Q1-62 - Q1-06 & CPI:ALL ITALY \\
\hline Japan & Q1-62 - Q2-06 & CPI:ALL JAPAN-485 ITEMS \\
\hline Jordan & Q1-78 - Q4-05 & CPI:EAST BANK-LOW\&MIDDLE INC \\
\hline Korea & Q1-72 - Q2-06 & CPI ALL CITIES \\
\hline Malaysia & Q1-72 - Q2-06 & CPI PENINSULAR MALAYSIA \\
\hline Mexico & Q1-62 - Q2-06 & CPI:ALL COUNTRY COMM.\&SERVICE \\
\hline Netherlands & Q1-62 - Q2-06 & CPI:WAGE EARNERS,MEDIAN INC. \\
\hline Nigeria & Q1-72 - Q2-06 & CPI:ALL INC. IN URBAN/RURAL AREAS \\
\hline Norway & Q1-62 - Q2-06 & CPI:NATIONAL ALL CONSUMERS \\
\hline Portugal & Q1-62 - Q2-06 & CPI CONTINENTAL \\
\hline Senegal & Q1-73-Q3-05 & CPI: DAKAR: ALL AFRICANS \\
\hline South Africa & Q1-62 - Q1-06 & CPI 12 URBAN AREAS,ALL INC GR \\
\hline Spain & Q1-63 - Q1-06 & CPI: (NO SPECIFICS AVAIL.) \\
\hline Sweden & Q1-62 - Q1-06 & CPI URBAN\&RURAL AREAS \\
\hline Switzerland & Q1-62 - Q1-06 & CPI:ALL COUNTRY \\
\hline United Kingdom & Q1-62 - Q1-06 & CPI: ALL ITEMS \\
\hline United States & Q1-62-Q2-06 & CPI All ITEMS CITY AVERAGE \\
\hline
\end{tabular}

Source: All data come directly from the October 2006 International Financial Statistics unless otherwise noted. 
Table A3: Original Data Sources and Descriptions for Output Measures by Country

\begin{tabular}{|c|c|c|}
\hline Countries & Series Dates Used & IFS Production Index Description \\
\hline Argentina & Q1-72 - Q4-05 & GDP 1970 Prices (australes) \\
\hline Australia & Q1-62 - Q2-06 & GDP AT 2001-02 PRICES \\
\hline Austria & Q1-62 - Q1-06 & INDUSTRIAL PRODUCTION \\
\hline Barbados & Q1-75 - Q1-06 & INDUSTRIAL PRODUCTION \\
\hline Belgium & Q1-62-Q2-06 & INDUSTRIAL PROD 2000 $=100$ \\
\hline Canada & Q1-62 - Q2-06 & GDP VOL. $(2000=100)$ \\
\hline Chile & Q1-62 - Q1-06 & MANUFACTURING PRODUCTION \\
\hline Cote d'Ivoire & Q1-70 - Q1-06 & INDUSTRIAL PRODUCTION \\
\hline Denmark & Q1-62 - Q1-06 & IND PROD \\
\hline Finland & Q1-62 - Q2-06 & INDUST PROD UNADJUSTED \\
\hline France & Q1-62 - Q1-06 & INDUST PRODUCTION unadjusted \\
\hline Germany & Q1-72 - Q1-06 & INDUSTRIAL PROD SA \\
\hline Greece & Q1-62 - Q1-06 & MANUFACTURING PRODUCTION \\
\hline India & Q1-62 - Q1-06 & INDUSTRIAL PRODUCTION \\
\hline Industrial countries & Q1-70 - Q2-06 & INDUSTRIAL PRODUCTION \\
\hline Ireland & Q1-62 - Q2-06 & INDUST'L PROD'N SEAS. ADJ. $(2000=100)$ \\
\hline Israel & Q1-62 - Q1-06 & INDUST PRODUCTION, SEAS ADJ \\
\hline Italy & Q1-62 - Q1-06 & INDUST.PRODUCTION UNADJ. \\
\hline Japan & Q1-62 - Q2-06 & IND.PROD.UNADJ. \\
\hline Jordan & Q1-78-Q4-05 & INDUSTRIAL PRODUCTION \\
\hline Korea & Q1-72-Q2-06 & INDUST PRODUCTION, SEAS ADJ \\
\hline Malaysia & Q1-72 - Q2-06 & INDUSTRIAL PRODUCTION \\
\hline Mexico & Q1-62 - Q2-06 & INDUSTRIAL PRODUCTION \\
\hline Netherlands & Q1-62 - Q2-06 & INDUSTRIAL PRODUCTION UNADJ. \\
\hline Nigeria & Q1-72-Q2-06 & INDUSTRIAL PRODUCTION \\
\hline Norway & Q1-62-Q2-06 & INDUSTRIAL PROD SEAS ADJUSTED \\
\hline Portugal & Q1-62 - Q2-06 & INDUST PRODUCTION, SEAS ADJ \\
\hline Senegal & Q1-73-Q3-05 & INDUSTRIAL PRODUCTION \\
\hline South Africa & Q1-62 - Q1-06 & GDP 2000 PRICES \\
\hline Spain & Q1-63 - Q1-06 & INDUST PRODUCTION UNADJ. \\
\hline Sweden & Q1-62 - Q1-06 & INDUST PRODUCTION UNADJ. \\
\hline Switzerland & Q1-62 - Q1-06 & INDUS. PROD SEAS. ADJ \\
\hline United Kingdom & Q1-62 - Q1-06 & IND.PROD(UNADJ) \\
\hline United States & Q1-62 - Q2-06 & GDP VOL. $(2000=100)$ \\
\hline
\end{tabular}

Source: All data come directly from the October 2006 International Financial Statistics unless otherwise noted. 


\section{Appendix 2 Pass-Through Estimates for Different Specifications}

Table A4: Breakpoints and Pass-Through Coefficients: Endogenous Windows

\begin{tabular}{|c|c|c|c|c|c|c|c|c|c|c|c|}
\hline & Start & Year & B 1 & B 2 & B 3 & & $\phi \mathbf{m 0}$ & $\phi \mathbf{m 1}$ & $\phi \mathbf{m} 2$ & $\phi \mathbf{m 3}$ & $\phi \mathbf{m} 4$ \\
\hline Argentina & & 72 & 82 & 89 & 96 & 3 & 0.00 & -0.30 & 4.83 & 0.02 & -0.02 \\
\hline Australia & & 62 & & & & 0 & 0.04 & & & & \\
\hline Austria & & 62 & 71 & & & 1 & 0.03 & -0.03 & 0.12 & & \\
\hline Barbados & & 75 & & & & 0 & 0.04 & & & & \\
\hline Belgium & & 62 & 71 & 85 & 94 & 3 & 0.05 & 0.77 & 0.05 & 0.02 & 0.02 \\
\hline Canada & & 62 & 91 & & & 1 & 0.04 & 0.05 & 0.02 & & \\
\hline Chile & & 62 & 74 & 83 & 92 & 3 & 30.47 & -0.04 & -0.16 & 0.08 & 0.13 \\
\hline Cote d'Ivoire & & 70 & & & & 0 & 0.03 & & & & \\
\hline Denmark & & 62 & 71 & & & 1 & 0.04 & 3.11 & 0.06 & & \\
\hline Finland & & 62 & 72 & 81 & 90 & 3 & 0.10 & -0.04 & -0.01 & -0.11 & 0.06 \\
\hline France & & 62 & 76 & 85 & 96 & 3 & 0.25 & 0.08 & 0.07 & 0.01 & 0.02 \\
\hline Germany & & 72 & & & & 0 & 0.00 & & & & \\
\hline Greece & & 62 & 74 & & & 1 & 0.01 & 0.11 & 0.27 & & \\
\hline India & & 62 & & & & 0 & 0.05 & & & & \\
\hline Ireland & & 62 & 81 & & & 1 & 0.20 & 0.58 & 0.03 & & \\
\hline Israel & & 62 & 76 & 85 & 94 & 3 & 1.16 & 0.36 & 0.00 & 0.04 & -0.08 \\
\hline Italy & & 62 & 74 & 83 & 94 & 3 & 0.42 & 0.02 & 0.03 & 0.07 & 0.02 \\
\hline Japan & & 62 & 70 & 80 & & 2 & 0.09 & -11.13 & 0.25 & 0.04 & \\
\hline Jordan & & 78 & 90 & & & 1 & 0.00 & 0.11 & 0.00 & & \\
\hline Korea & & 72 & 80 & & & 1 & 0.20 & 0.07 & 0.03 & & \\
\hline Malaysia & & 72 & 84 & & & 1 & -0.02 & -0.02 & -0.01 & & \\
\hline Mexico & & 62 & 79 & 88 & 97 & 3 & 0.25 & 0.04 & 0.11 & 0.13 & -0.18 \\
\hline Netherlands & & 62 & 70 & 82 & & 2 & 0.05 & -2.76 & 0.17 & 0.01 & \\
\hline Nigeria & & 72 & & & & 0 & -0.07 & & & & \\
\hline Norway & & 62 & 91 & & & 1 & 0.04 & 0.03 & 0.01 & & \\
\hline Portugal & & 62 & 77 & & & 1 & 0.12 & 0.67 & -0.08 & & \\
\hline Senegal & & 73 & 81 & & & 1 & 0.14 & 0.31 & -0.05 & & \\
\hline South Africa & & 62 & 72 & 95 & & 2 & 0.00 & 0.01 & -0.01 & -0.03 & \\
\hline Spain & & 63 & & & & 0 & 0.09 & & & & \\
\hline Sweden & & 62 & 91 & & & 1 & 0.05 & 0.04 & 0.00 & & \\
\hline Switzerland & & 62 & 95 & & & 1 & 0.00 & 0.00 & 0.02 & & \\
\hline United Kingdom & & 62 & 79 & & & 1 & 0.28 & 0.63 & -0.07 & & \\
\hline United States & & 62 & 81 & & & 1 & 0.08 & 0.07 & 0.03 & & \\
\hline
\end{tabular}

Source: Authors' calculations.

Note: $\phi \mathbf{m 0}$ refers to the long run passthrough coefficient from equation 2 in the absence of breaks. $\phi \mathbf{m} \mathbf{1}$ through $\phi$ $\mathbf{m} 4$, represent the passthrough coefficient calculated for each parte of the series using the estimated breaks if any. 
Table A5: Breakpoints and Pass-Through Coefficients: Endogenous Windows Using National

\begin{tabular}{|c|c|c|c|c|c|c|c|c|c|c|}
\hline & Start Year & B 1 & B 2 & B 3 & & $\phi \mathbf{m 0}$ & $\phi \mathbf{m} \mathbf{1}$ & $\phi \mathbf{m 2}$ & $\phi \mathbf{m 3}$ & $\phi \mathbf{m 4}$ \\
\hline Argentina & 72 & 83 & 90 & & 2 & -1.30 & -0.41 & -0.37 & 0.00 & \\
\hline Australia & 62 & & & & 0 & 0.03 & & & & \\
\hline Austria & 62 & 71 & 84 & 96 & 3 & 0.02 & 1.19 & 0.01 & 0.00 & 0.02 \\
\hline Barbados & 75 & & & & 0 & 0.04 & & & & \\
\hline Belgium & 62 & 71 & 85 & 94 & 3 & 0.03 & -1.05 & 0.04 & 0.01 & 0.02 \\
\hline Canada & 62 & 91 & & & 1 & 0.04 & 0.04 & 0.02 & & \\
\hline Chile & 62 & 73 & 85 & & 2 & -0.70 & -0.07 & -0.50 & 0.58 & \\
\hline Cote d'Ivoire & 70 & & & & 0 & 0.00 & & & & \\
\hline Denmark & 62 & & & & 0 & 0.03 & & & & \\
\hline Finland & 62 & 70 & 80 & & 2 & 0.05 & -0.17 & -0.01 & 0.05 & \\
\hline France & 62 & 76 & 85 & 96 & 3 & 0.28 & 0.09 & 0.05 & 0.01 & 0.07 \\
\hline Germany & 72 & & & & 0 & 0.00 & & & & \\
\hline Greece & 62 & 74 & & & 1 & -0.01 & 0.11 & 0.25 & & \\
\hline India & 62 & 75 & & & 1 & 0.02 & 0.03 & -0.03 & & \\
\hline Ireland & 62 & 77 & 86 & & 2 & 0.21 & 0.16 & 0.00 & 0.02 & \\
\hline Israel & 62 & 75 & 85 & 94 & 3 & 0.55 & 0.39 & -0.88 & 0.03 & -0.08 \\
\hline Italy & 62 & 80 & & & 1 & 0.45 & 0.25 & 0.06 & & \\
\hline Japan & 62 & 75 & & & 1 & 0.12 & 0.07 & 0.03 & & \\
\hline Jordan & 78 & 88 & & & 1 & 0.00 & 0.10 & 0.00 & & \\
\hline Korea & 72 & 79 & 86 & 98 & 3 & 0.32 & 0.03 & 0.11 & 0.04 & 0.02 \\
\hline Malaysia & 72 & 84 & & & 1 & -0.02 & 0.00 & -0.01 & & \\
\hline Mexico & 62 & 79 & 88 & 97 & 3 & -0.25 & 0.01 & 0.04 & 0.00 & -0.13 \\
\hline Netherlands & 62 & 82 & & & 1 & 0.01 & 0.03 & 0.01 & & \\
\hline Nigeria & 72 & & & & 0 & -0.05 & & & & \\
\hline Norway & 62 & 90 & & & 1 & 0.04 & 0.04 & 0.03 & & \\
\hline Portugal & 62 & 84 & & & 1 & 0.01 & 0.11 & 0.00 & & \\
\hline Senegal & 73 & & & & 0 & 0.00 & & & & \\
\hline South Africa & 62 & 72 & 95 & & 2 & 0.00 & 0.02 & -0.01 & -0.04 & \\
\hline Spain & 65 & & & & 0 & 0.20 & & & & \\
\hline Sweden & 62 & 71 & 91 & & 2 & 0.05 & -0.64 & 0.01 & -0.01 & \\
\hline Switzerland & 62 & 95 & & & 1 & 0.00 & 0.01 & 0.02 & & \\
\hline United Kingdom & 62 & 79 & & & 1 & 0.26 & 0.74 & 0.06 & & \\
\hline United States & 62 & 81 & & & 1 & 0.08 & 0.07 & 0.03 & & \\
\hline
\end{tabular}

Source: Authors' calculations.

Note: See Table A4. 
Table A6: Breakpoints and Pass-Through Coefficients: Endogenous Windows Using Oil Intensity and Prices in National Currency

\begin{tabular}{|c|c|c|c|c|c|c|c|c|c|c|}
\hline & Start Year & B 1 & B 2 & B 3 & & $\phi \mathbf{m 0}$ & $\phi \mathbf{m} \mathbf{1}$ & $\phi \mathbf{m} 2$ & $\phi \mathbf{m} 3$ & $\phi \mathbf{m} 4$ \\
\hline Argentina & 72 & 83 & 90 & & 2 & -1.32 & -0.43 & -0.36 & -0.11 & \\
\hline Australia & 67 & & & & 0 & 0.03 & & & & \\
\hline Austria & 67 & 76 & 84 & 96 & 3 & 0.11 & 0.02 & -0.04 & 0.00 & 0.05 \\
\hline Belgium & 67 & 74 & 85 & & 2 & 0.02 & 0.13 & -0.01 & 0.01 & \\
\hline Canada & 67 & 91 & & & 1 & 0.01 & 0.03 & 0.02 & & \\
\hline Chile & 67 & 74 & 82 & 90 & 3 & -0.71 & -1.68 & 0.89 & -0.05 & 0.21 \\
\hline Denmark & 67 & 76 & & & 1 & 0.06 & -0.01 & 0.06 & & \\
\hline Finland & 67 & 80 & & & 1 & 0.16 & 0.01 & 0.04 & & \\
\hline France & 67 & 76 & 85 & 93 & 3 & 0.35 & 0.12 & 0.06 & 0.00 & 0.02 \\
\hline Greece & 67 & & & & 0 & 0.11 & & & & \\
\hline India & 67 & 76 & & & 1 & 0.05 & 0.07 & -0.02 & & \\
\hline Ireland & 67 & 76 & 84 & & 2 & 0.26 & 0.03 & -0.41 & 0.02 & \\
\hline Italy & 67 & 80 & & & 1 & 0.56 & 0.24 & 0.06 & & \\
\hline Japan & 67 & 75 & & & 1 & 0.11 & 0.08 & 0.03 & & \\
\hline Korea & 72 & 80 & & & 1 & 0.16 & 0.08 & 0.03 & & \\
\hline Malaysia & 72 & 84 & 90 & 98 & 3 & -0.02 & -0.01 & 0.01 & -0.01 & 0.00 \\
\hline Mexico & 67 & 79 & 88 & 96 & 3 & -0.27 & 0.00 & -0.01 & 0.00 & -0.12 \\
\hline Netherlands & 67 & & & & 0 & 0.02 & & & & \\
\hline Norway & 67 & & & & 0 & 0.03 & & & & \\
\hline Portugal & 67 & 75 & 85 & & 2 & 0.01 & 0.12 & -0.06 & 0.00 & \\
\hline South Africa & 67 & 95 & & & 1 & 0.00 & -0.02 & -0.05 & & \\
\hline Spain & 69 & 77 & & & 1 & 0.28 & 0.00 & 0.00 & & \\
\hline Sweden & 67 & 91 & & & 1 & 0.03 & 0.02 & 0.00 & & \\
\hline Switzerland & 67 & 95 & & & 1 & 0.01 & 0.01 & 0.01 & & \\
\hline United Kingdom & 67 & 77 & & & 1 & 0.12 & 0.01 & 0.03 & & \\
\hline United States & 67 & 81 & & & 1 & 0.08 & 0.03 & 0.03 & & \\
\hline
\end{tabular}

Source: Authors' calculations.

Note: See Table A4. 


\section{Appendix 3 Break Tests}

Table A7: Break Date Statistics

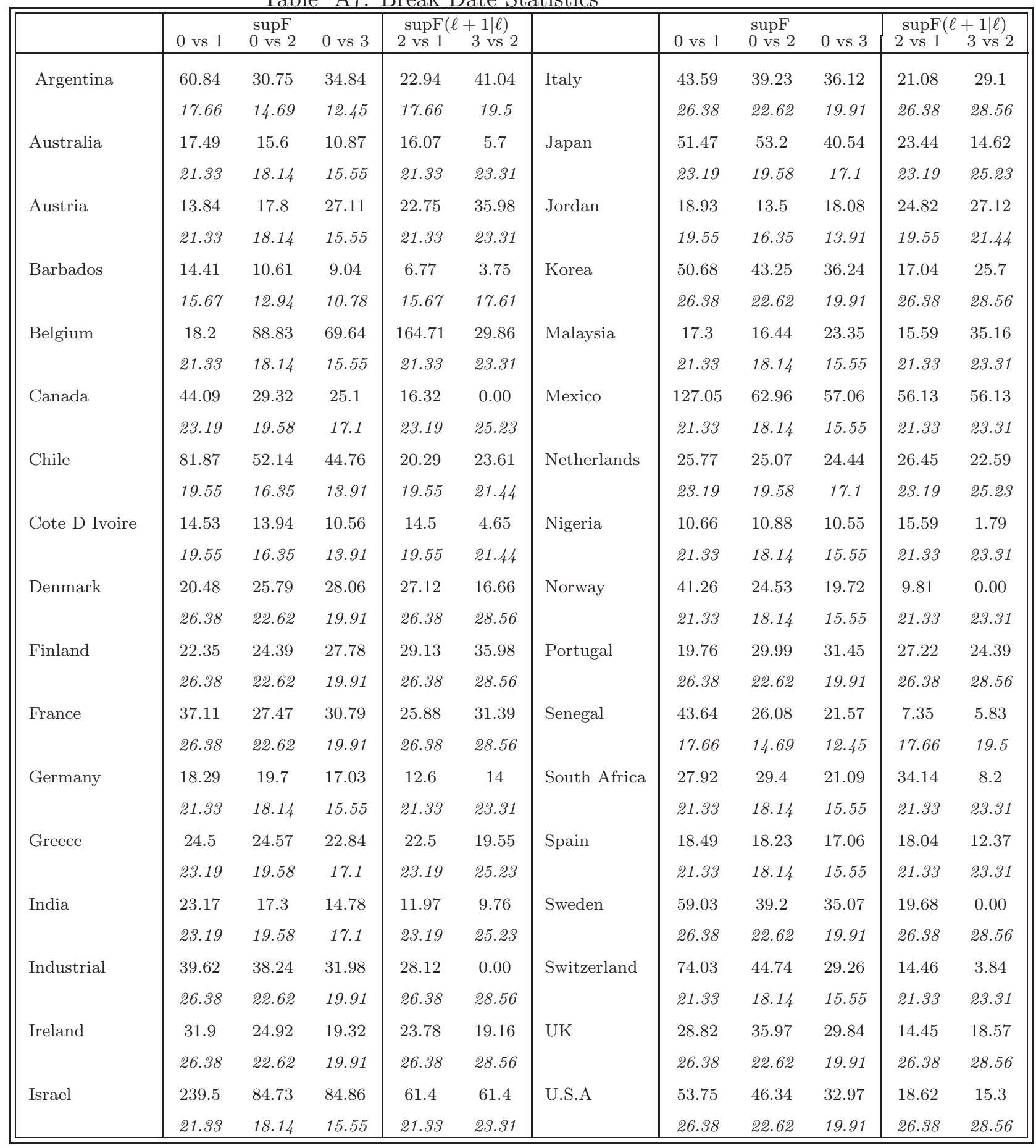

Source: Authors' calculations.

Note: The tests include supF tests of the null of no breaks versus a fixed number of breaks and the $\operatorname{supF}(\ell+1 \mid \ell)$ of one more break given $\ell$ breaks. The values in the second row for each country correspond to the critical values at the 5 percent confidence level. 


\section{Appendix 4 Rolling Windows and Impulse Responses}

Figure A13: Impulse Response of a Unit Oil Shock on Inflation: Rolling Windows

(shock measured as 1 U.S.\$)
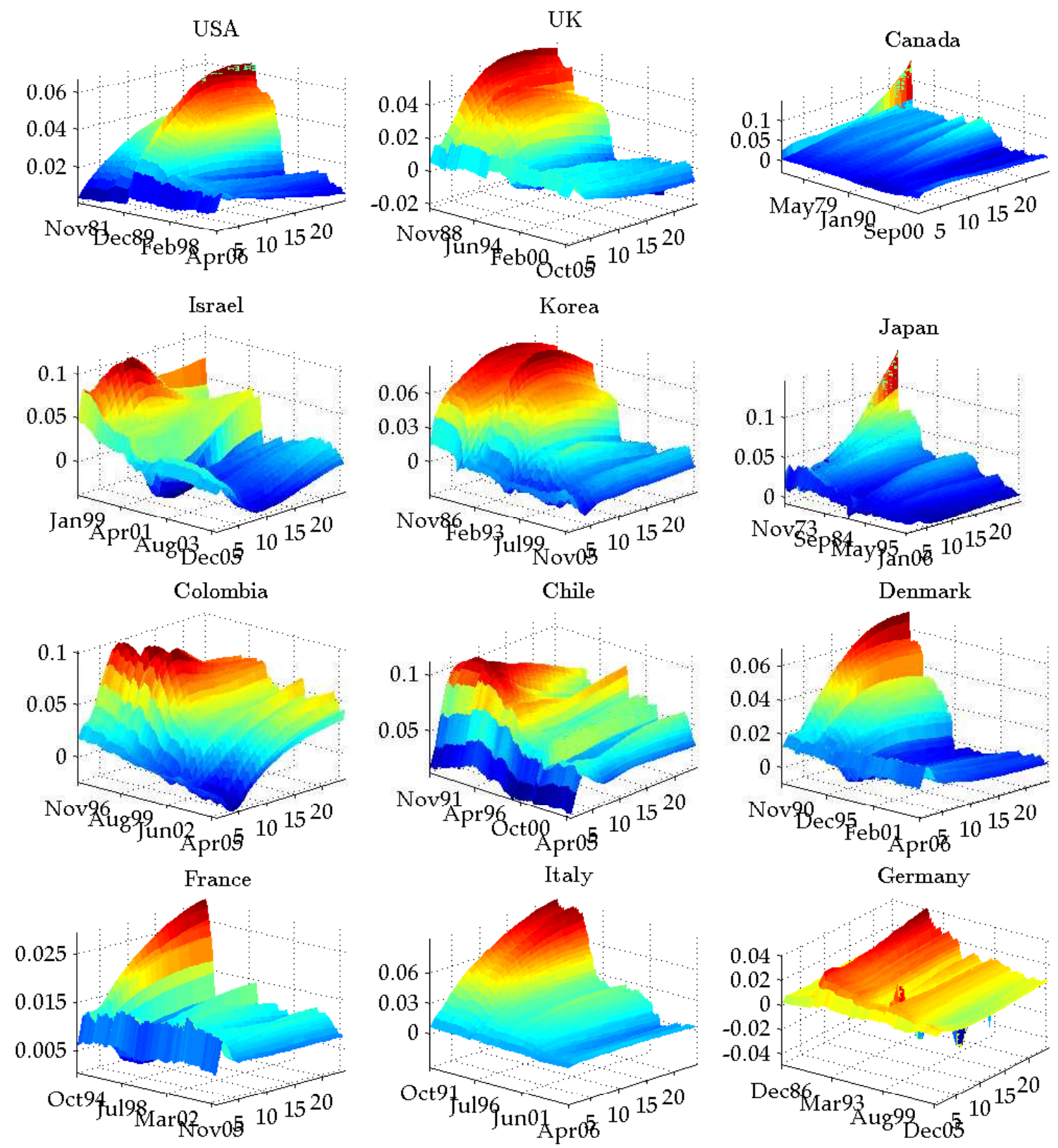

Note: Shocks are measured as a one unit- $\log$ U.S. dollar change in the oil price. The accumulated effect of each impulse response is presented in Figure 8. 